OPEN ACCESS

Edited by: Philippe Hinsinger, INRA, France

Reviewed by:

Delia B. Rodriguez-Amaya, University of Campinas, Brazil Alain Mollier,

INRA, France

${ }^{*}$ Correspondence:

Eva Brod eva.brod@nibio.no

Specialty section:

This article was submitted to Nutrition and Environmental Sustainability,

a section of the journal

Frontiers in Nutrition

Received: 01 February 2016 Accepted: 26 April 2016

Published: 12 May 2016

Citation:

Brod E, Øgaard AF, Krogstad T, Haraldsen TK, Frossard E and Oberson A (2016) Drivers of Phosphorus Uptake by Barley Following Secondary Resource Application. Front. Nutr. 3:12. doi: 10.3389/fnut.2016.00012

\section{Drivers of Phosphorus Uptake by Barley Following Secondary Resource Application}

\author{
Eva Brod ${ }^{1,2 *}$, Anne Falk Øgaard ${ }^{1}$, Tore Krogstad ${ }^{2}$, Trond Knapp Haraldsen ${ }^{1}$, \\ Emmanuel Frossard ${ }^{3}$ and Astrid Oberson ${ }^{3}$
}

${ }^{1} \mathrm{NIBIO}$, Norwegian Institute of Bioeconomy Research, Ås, Norway, ${ }^{2}$ Department of Environmental Sciences, Norwegian University of Life Sciences, Ås, Norway, ${ }^{3}$ Institute for Agricultural Sciences, ETH Zürich, Lindau, Switzerland

Minable rock phosphate is a finite resource. Replacing mineral phosphorus $(P)$ fertilizer with $\mathrm{P}$-rich secondary resources is one way to manage $\mathrm{P}$ more efficiently, but the importance of physicochemical and microbial soil processes induced by secondary resources for plant $\mathrm{P}$ uptake is still poorly understood. Using radioactive-labeling techniques, the fertilization effects of dairy manure, fish sludge, meat bone meal, and wood ash were studied as $\mathrm{P}$ uptake by barley after 44 days and compared with those of water-soluble mineral $\mathrm{P}(\mathrm{MinP})$ and an unfertilized control (NoP) in a pot experiment with an agricultural soil containing little available $\mathrm{P}$ at two soil pH levels, approximately $\mathrm{pH} 5.3$ (unlimed soil) and pH 6.2 (limed soil). In a parallel incubation experiment, the effects of the secondary resources on physicochemical and microbial soil processes were studied. The results showed that the relative agronomic efficiency compared with MinP decreased in the order: manure $\geq$ fish sludge $\geq$ wood ash $\geq$ meat bone meal. The solubility of inorganic $P$ in secondary resources was the main driver for $\mathrm{P}$ uptake by barley (Hordeum vulgare). The effects of secondary resources on physicochemical and microbial soil processes were of little overall importance. Application of organic carbon with manure resulted in microbial $\mathrm{P}$ immobilization and decreased uptake by barley of $\mathrm{P}$ derived from the soil. On both soils, $\mathrm{P}$ uptake by barley was best explained by a positive linear relationship with the $\mathrm{H}_{2} \mathrm{O}+\mathrm{NaHCO}_{3}$-soluble inorganic $\mathrm{P}$ fraction in fertilizers or by a linear negative relationship with the $\mathrm{HCl}$-soluble inorganic $\mathrm{P}$ fraction in fertilizers.

Keywords: waste products, fish sludge, meat bone meal, wood ash, animal manure, isotope techniques

\section{INTRODUCTION}

Minable rock phosphate is a finite resource. However, industrialized agroecosystems are today far from managing phosphorus $(\mathrm{P})$ efficiently and Europe's food production is largely dependent on imports of mined rock phosphate (1). The greatest reductions in $\mathrm{P}$ imports could be achieved by replacing mineral fertilizer with recycled P from secondary resources (2). In food systems, the

\footnotetext{
Abbreviations: P fert, $\mathrm{P}$ applied with the fertilizer; P uptake, $\mathrm{P}$ taken up by plant in aboveground biomass; Pdf fertilizer, $\mathrm{P}$ derived from the fertilizer; Pdf seed, P derived from the seed; Pdf soil, P derived from the soil; Pdff ResinP, Resin P deriving from the fertilizer; Pi, inorganic P; RAE, relative agronomic efficiency; SA, specific activity.
} 
accumulated P content in secondary resources is often of the same order of magnitude as that in mineral fertilizer, as shown for Europe (3). In Norway, the total amount of $\mathrm{P}$ in secondary resources $\left(27,700 \mathrm{MgP}\right.$ year $\left.^{-1}\right)$ actually greatly exceeds the amount of $\mathrm{P}$ applied to soil with mineral fertilizer $\left(8400 \mathrm{Mg} \mathrm{P}_{\text {year }}{ }^{-1}\right)$ and the amount of $\mathrm{P}$ removed by crops (11,000 Mg P year $\left.{ }^{-1}\right)$ (4). The Norwegian secondary resources containing the largest amounts of $\mathrm{P}$ are manure $\left(11,000 \mathrm{Mg} \mathrm{P}\right.$ year $\left.{ }^{-1}\right)$, fish excrement, and feed losses from salmon and trout farming in open cages in fjords (fish sludge, $9000 \mathrm{Mg} \mathrm{P}$ year ${ }^{-1}$ ), meat bone meal (2100 Mg P year ${ }^{-1}$ ), and sewage (3100 Mg P year ${ }^{-1}$ ) (4). Wood ash, a residue from bioenergy plants and industrial timber production, also contains considerable amounts of secondary $\mathrm{P}\left(800 \mathrm{Mg} \mathrm{P}_{\text {year }}{ }^{-1}\right)$ (5).

The $\mathrm{P}$ recycling potential of secondary resources is determined by, among other parameters, the solubility of the $\mathrm{P}$ species they contain $(6,7)$. Phosphorus in secondary resources is generally present as a complex mixture of inorganic $\mathrm{P}$ species, predominantly calcium $(\mathrm{Ca})$ phosphates with differing solubility but also amorphous aluminum (Al)- or iron (Fe)-bound $\mathrm{P}$, while organic $\mathrm{P}$ usually represents a small fraction (8). The P fertilization effects of secondary resources can be considerably affected by the $\mathrm{pH}$ in the target soil (7), as the solubility of Ca phosphates decreases with increasing soil $\mathrm{pH}$, whereas the solubility of Al-/Fe-bound $\mathrm{P}$ decreases with decreasing soil $\mathrm{pH}$ (9). The best method for predicting the $\mathrm{P}$ fertilization effects of secondary resources also depends on the $\mathrm{pH}$ in the target soil (10). In a previous bioassay with ryegrass (Lolium multiflorum) grown in a sand-peat substrate containing little available $\mathrm{P}$, the apparent $\mathrm{P}$ use efficiency of nine different secondary resources with predominantly Ca-bound $\mathrm{P}$ was best explained by a positive relationship with $\mathrm{H}_{2} \mathrm{O}$-soluble inorganic $\mathrm{P}$ in acid soil and a negative relationship with $\mathrm{HCl}$-soluble inorganic $\mathrm{P}$ in a near-neutral soil (7).

Plant P uptake following secondary resource application can also be influenced by their effects on microbial or physicochemical processes in the soil. Many secondary resources contain organic matter, meaning that organic carbon $(C)$ is applied to the soil when they are used as alternatives to mineral fertilizers (e.g., manure, fish sludge, and meat bone meal). Organic $\mathrm{C}$ application can trigger microbial activity, which may result in immobilization of soil $\mathrm{P}$ and fertilizer $\mathrm{P}(11,12)$ and in microbes competing with plants for available P. Microbial activity can also increase P availability by affecting physicochemical processes. Low molecular weight organic acids excreted by microorganisms during the breakdown of organic $\mathrm{C}$ have been shown to reduce phosphate retention on soil particles (13). Furthermore, these acids can solubilize P by complexing metal cations such as $\mathrm{Al}, \mathrm{Fe}$, and $\mathrm{Ca}$ that associate with $\mathrm{P}$ in insoluble forms, or by decreasing soil $\mathrm{pH}$ (14). Other secondary resources contain inorganic $\mathrm{C}$, for example, in the form of calcium carbonate $\left(\mathrm{CaCO}_{3}\right)$ (e.g., wood ash), which neutralizes $\mathrm{pH}$ in acid soils. Moreover, the solubility of applied fertilizer $\mathrm{P}$ can affect physicochemical soil processes depending on equilibrium processes in the target soil, since increased phosphate concentration in the soil solution can in turn result in reduced phosphate release from the soil (15).

To date, the $\mathrm{P}$ fertilization effects of fish sludge, meat bone meal, and wood ash have only been studied by the difference method $(7,16-18)$. This method compares the $\mathrm{P}$ uptake by a plant fertilized with the secondary resource with the $\mathrm{P}$ uptake by a plant receiving no $\mathrm{P}$ fertilizer (NoP). The difference in $\mathrm{P}$ uptake between the two treatments is defined as the P fertilization effect of the secondary resource. The underlying assumption in the difference method is that unfertilized and fertilized plants take up the same amount of $\mathrm{P}$ from the soil, i.e., that the secondary resource does not affect soil $\mathrm{P}$ availability. However, the effects of secondary resources such as fish sludge, meat bone meal, and wood ash on microbial and physicochemical soil $\mathrm{P}$ processes are still poorly understood, and it is not known whether the difference method actually reflects the net P fertilization effects of these secondary resources. Understanding the effects of complex secondary resources on soil processes is therefore important for a holistic evaluation of their fertilization effects.

Using radioisotopes of $\mathrm{P}$ in growth and incubation experiments provides the possibility to study $\mathrm{P}$ processes in soil/plant systems. In growth experiments, labeling soil with radioisotopes of $\mathrm{P}$ before application of secondary resources is a way to differentiate $\mathrm{P}$ taken up by the plants deriving from the fertilizer and from the soil (19-21). In incubation experiments, isotopic dilution can be used to study the incorporation of fertilizer into different soil $\mathrm{P}$ pools (22) or to quantify the amount of isotopically exchangeable phosphate (E-value) as affected by fertilizer application [e.g., Ref. $(15,20)]$.

The aim of this study was to determine the main drivers of plant $\mathrm{P}$ uptake following secondary resource application. To this end, the $\mathrm{P}$ fertilization effects of dairy manure (manure), fish sludge, meat bone meal, and wood ash were compared with those of water-soluble mineral $\mathrm{P}$ fertilizer (MinP) in a pot experiment with barley (Hordeum vulgare var. Heder) by ${ }^{33} \mathrm{P}$ labeling of a loam soil at two soil pH levels (unlimed and limed). In parallel, soil incubation experiments were conducted to study the effects of the secondary resources on physicochemical and microbial soil processes and to explore their importance for plant P uptake.

\section{MATERIALS AND METHODS}

\section{Secondary Resources}

The secondary resources are described in Table 1, while Table 2 gives an overview of their selected chemical properties. The secondary resources were also analyzed for heavy metal concentrations by ICP-OES after digestion in concentrated nitric acid in an ultraclave (23) (results not shown). Based on their heavy metal concentrations and Norwegian regulations (24), all the secondary resources studied here were eligible for application as fertilizer to agricultural land.

\section{Experimental Soil}

The experimental soil originated from plots in a long-term field experiment in Norway $\left(59^{\circ} 39^{\prime} 48.0^{\prime \prime} \mathrm{N} 10^{\circ} 45^{\prime} 40.8^{\prime \prime} \mathrm{E}\right)$ that has received $0 \mathrm{~kg} \mathrm{P}$ year ${ }^{-1}$ and 0 or $5 \mathrm{~kg}$ potassium $(\mathrm{K})$ year ${ }^{-1}$ since 1966. It is classified as an Albeluvisol in the World Reference Base for Soil Resources (31) and contains 27\% clay, $40 \%$ silt, and 33\% sand. Selected chemical characteristics of the soil are presented 
TABLE 1 | Description of secondary resources and identified P characteristics (7).

\begin{tabular}{|c|c|c|}
\hline Product & Description & $\begin{array}{l}\text { Inorganic P } \\
\text { characteristics }\end{array}$ \\
\hline Manure & $\begin{array}{l}\text { Dried slurry (feces and urine) of dairy } \\
\text { cows collected from the barn at the } \\
\text { Norwegian University of Life Sciences, } \\
\text { Norway }\end{array}$ & $\begin{array}{l}\text { Mainly readily available } \\
\left(\mathrm{H}_{2} \mathrm{O} \text {-soluble) and labile }\right. \\
\text { ( } \mathrm{NaHCO}_{3} \text {-soluble) } \mathrm{Pi} \\
\text { without further speciation }\end{array}$ \\
\hline $\begin{array}{l}\text { Fish } \\
\text { sludge }\end{array}$ & $\begin{array}{l}\text { Collected from the on-land Åsen } \\
\text { settefisk salmon hatchery, Norway. } \\
\text { Fish are bred in closed cages until } \\
\text { they are approximately } 1 \text { year old. } \\
\text { Effluent containing feces and feed } \\
\text { residues (mainly fish meal and soya) } \\
\text { was mechanically filtered before the } \\
\text { material was treated on-site in a } \\
\text { reactor developed by the company } \\
\text { Global Enviro }\end{array}$ & $\begin{array}{l}\text { Stable Ca-bound P } \\
\text { such as apatite, but also } \\
\text { amorphous Ca-bound P }\end{array}$ \\
\hline $\begin{array}{l}\text { Meat bone } \\
\text { meal }\end{array}$ & $\begin{array}{l}\text { Commercial product originating from } \\
\text { a slaughterhouse in Hamar, Norway, } \\
\text { and merchandized by Norsk Protein } \\
\text { AS. Slaughterhouse waste of category } \\
\text { III according to EC (25), which was } \\
\text { stabilized and sanitized at } 133^{\circ} \mathrm{C} \text { and } \\
3.0 \text { bar for } 20 \text { min }\end{array}$ & $\begin{array}{l}\text { Stable Ca-bound P, } \\
\text { mainly apatite }\end{array}$ \\
\hline Wood ash & $\begin{array}{l}\text { Bottom ash from a grate-fired } \\
\text { boiler system at the Moelven } \\
\text { Østerdalsbruket AS mill, Norway. } \\
\text { Parent material was timber unsuitable } \\
\text { for industrial use }\end{array}$ & $\begin{array}{l}\text { Stable Ca-P, mainly } \\
\text { calcium phosphate } \\
\text { silicate, and amorphous } \\
\text { P. May also contain Al-/ } \\
\text { Fe-bound P }\end{array}$ \\
\hline
\end{tabular}

in Table 3. This soil was chosen because of its low content of plant-available $\mathrm{P}$ [measured as ammonium lactate-extractable $\mathrm{P}$ (P-AL)], in order to avoid $\mathrm{P}$ fertilization effects being masked by soil P. Before the soil was sampled at the end of the growing season in November 2013, barley, wheat and oats were grown in rotation for 16 years, with the last year of grass production being in 1997. After harvest of the cereals, including the straw, the soil was usually plowed in autumn. During sampling, random soil cores were taken from the $0-20 \mathrm{~cm}$ horizon in the middle of the plots. The soil was air-dried before sieving at mesh width $5 \mathrm{~mm}$. To study the effect of soil $\mathrm{pH}$ on $\mathrm{P}$ uptake following secondary resource application, one part of the soil was limed with $2 \mathrm{~g} \mathrm{CaCO}_{3} \mathrm{~kg}^{-1}$ soil dry matter (DM). Then, both the unlimed and the limed soils were incubated in portions of $15 \mathrm{~kg}$ at $60 \%$ of water-holding capacity (WHC, $100 \% \mathrm{WHC}=447 \mathrm{~g} \mathrm{H}_{2} \mathrm{O} \mathrm{kg}^{-1}$ soil) for 2.5 months in the dark before drying at $40^{\circ} \mathrm{C}$. After transportation to Switzerland, the soil was again sieved at mesh width of $5 \mathrm{~mm}$, carefully rewetted in portions of $1 \mathrm{~kg}$ soil DM, and incubated at $40 \%$ of WHC for at least 3 weeks. The pre-incubation aimed at reaching constant microbial activity, in order to minimize a microbial boost during setup of the experiment. When the experiments were set up, soil $\mathrm{pH}$ (measured in $\mathrm{H}_{2} \mathrm{O}$ ) was 5.3 and 6.2 in the unlimed and limed soil, respectively.

\section{Pot Experiment}

The $\mathrm{P}$ fertilization effects of secondary resources were studied in a pot experiment using indirect labeling with ${ }^{33} \mathrm{P}(21)$. Preincubated portions of $1 \mathrm{~kg}$ soil DM were mixed with carrier-free
TABLE 2 | Selected chemical properties of secondary resources.

\begin{tabular}{|c|c|c|c|c|c|}
\hline & & Manure & $\begin{array}{c}\text { Fish } \\
\text { sludge }\end{array}$ & $\begin{array}{c}\text { Meat bone } \\
\text { meal }\end{array}$ & $\begin{array}{c}\text { Wood } \\
\text { ash }\end{array}$ \\
\hline Dry mattera & $\mathrm{g} 100 \mathrm{~g}^{-1}$ & 5.8 & 95.0 & 96.2 & 99.6 \\
\hline Organic matter ${ }^{b}$ & g $100 \mathrm{~g}^{-1} \mathrm{DM}$ & 81.6 & 87.6 & 66.6 & 0.0 \\
\hline $\mathrm{pH}^{\mathrm{c}}$ & & 7.0 & 5.4 & 6.2 & 13 \\
\hline$P^{d}$ & $\mathrm{~g} \mathrm{~kg}^{-1} \mathrm{DM}$ & 6 & 21 & 54 & 17 \\
\hline $\mathrm{Po}^{d}$ & $\%$ of $\mathrm{P}$ & 24 & 14 & 2 & n.d. \\
\hline $\mathrm{P}_{\mathrm{H}_{2} \mathrm{O}}$ & $\%$ of $\mathrm{P}$ & 42 & 19 & 4 & n.d. \\
\hline $\mathrm{P}_{\mathrm{NaHCO}_{3}{ }^{e}}$ & $\%$ of $\mathrm{P}$ & 33 & 19 & 5 & 43 \\
\hline $\mathrm{P}_{\mathrm{NaOH}}{ }^{e}$ & $\%$ of $\mathrm{P}$ & 4 & 12 & 3 & n.d. \\
\hline $\mathrm{P}_{\mathrm{HCl}}^{e}$ & $\%$ of $\mathrm{P}$ & 2 & 37 & 88 & 63 \\
\hline $\mathrm{C}^{\mathrm{f}}$ & $\mathrm{g} \mathrm{kg}^{-1} \mathrm{DM}$ & 470 & 503 & 368 & 19 \\
\hline Organic $\mathrm{C}^{g}$ & $\mathrm{~g} \mathrm{~kg}^{-1} \mathrm{DM}$ & 393 & 375 & 266 & 0.1 \\
\hline Organic $\mathrm{C}_{\mathrm{H}_{2} \mathrm{O}}{ }^{n}$ & $\%$ of organic C & 14 & 34 & 41 & n.d. \\
\hline $\mathrm{N}^{\mathrm{i}}$ & $\mathrm{g} \mathrm{kg}^{-1} \mathrm{DM}$ & 53 & 71 & 86 & n.d. \\
\hline Nmini & $\mathrm{g} \mathrm{kg}^{-1} \mathrm{DM}$ & 22 & 2.6 & 5.0 & n.d. \\
\hline $\mathrm{K}^{\mathrm{K}}$ & $\mathrm{g} \mathrm{kg}^{-1} \mathrm{DM}$ & 42 & 3 & 4 & 56 \\
\hline $\mathrm{Mg}^{\mathrm{k}}$ & $\mathrm{g} \mathrm{kg}^{-1} \mathrm{DM}$ & 6 & 3 & 3 & 25 \\
\hline$S^{k}$ & $\mathrm{~g} \mathrm{~kg}^{-1} \mathrm{DM}$ & 42 & 48 & 34 & 34 \\
\hline $\mathrm{Ca}^{\mathrm{k}}$ & $\mathrm{g} \mathrm{kg}^{-1} \mathrm{DM}$ & 11 & 37 & 110 & 310 \\
\hline$A l^{k}$ & $\mathrm{~g} \mathrm{~kg}^{-1} \mathrm{DM}$ & 0.4 & 0.3 & 0.2 & 19.1 \\
\hline $\mathrm{Fe}^{\mathrm{k}}$ & $\mathrm{g} \mathrm{kg}^{-1} \mathrm{DM}$ & 1.3 & 0.7 & 0.5 & 7.6 \\
\hline
\end{tabular}

Po, organic P; Nmin, mineral $N\left(N_{3}^{-}\right.$and $\left.\mathrm{NH}_{4}^{+}\right)$; n.d., not detectable.

${ }^{a}$ Drying of the original samples at $105^{\circ} \mathrm{C}$.

${ }^{b}$ Incineration of the original samples at $550^{\circ} \mathrm{C}$.

'Measured on dried and sieved $(<2 \mathrm{~mm})$ samples in $\mathrm{H}_{2} \mathrm{O}$ in a solid:solution ratio of

$1: 2.5(\mathrm{v} / \mathrm{V})$.

${ }^{d}$ By ignition method on dried and milled samples before extraction with $6 \mathrm{M} \mathrm{H}_{2} \mathrm{SO}_{4}$ according to Møberg and Petersen (26). Colorimetric analysis according to Murphy and Riley (27).

eSequentially extracted Pi of $1 \mathrm{~g}$ dried and milled sample in $200 \mathrm{~mL} \mathrm{H}_{2} \mathrm{O}$ for $1 \mathrm{~h}$, $200 \mathrm{~mL} \mathrm{0.5M} \mathrm{NaHCO}, 0.1 \mathrm{M} \mathrm{NaOH}$, and $1 \mathrm{M} \mathrm{HCl}$ for each $16 \mathrm{~h}$. Colorimetric analysis according to Murphy and Riley (27).

${ }^{\dagger} \mathrm{C} / \mathrm{N}$ elemental analysis (Leco TruSpec CHN) on dried and milled samples. ${ }^{9}$ Analyzed on triplicate dried and milled samples after washing with $2 \mathrm{M} \mathrm{HCl}$ solution using a Perkin Elmer 2400 CHN analyzer.

hExtraction of $1 \mathrm{~g}$ dried and sieved sample in $200 \mathrm{~mL} \mathrm{H} \mathrm{H}_{2} \mathrm{O}$ for $2 \mathrm{~h}$, analyzed on Shimadzu TOC-V CPN.

'Modified Kjeldahl method (28) analyzed on Leco TruSpec CHN. Analyzed on a liquid sample of manure.

'Analyzed on Konelab Aqua 60 analyzer after extraction with $2 \mathrm{M} \mathrm{KCl}(29,30)$. Analyzed on a liquid sample of manure.

${ }^{k}$ Analyzed by ICP-OES after digestion of dried and milled samples with concentrated nitric acid in an ultraclave (23).

${ }^{33} \mathrm{P}$-orthophosphate at a rate of $1.1 \mathrm{MBq} \mathrm{kg}^{-1}$ soil, which was added after dilution in $\mathrm{H}_{2} \mathrm{O}$ by $10 \mathrm{~mL} \mathrm{~kg}{ }^{-1}$ soil. The soil was transferred into pots with sealed bottoms and again incubated at $16-18^{\circ} \mathrm{C}$ for 10 days to reach near-equilibrium conditions for the pools of plant-available ${ }^{31} \mathrm{P}$ and ${ }^{33} \mathrm{P}$ in the soil. Pots containing the same amount of unlabeled soil were also mixed and kept under the same conditions. The fertilization effects of manure, fish sludge, meat bone meal, and wood ash (all dried at $55^{\circ} \mathrm{C}$ and sieved at $\leq 2 \mathrm{~mm}$ ) were compared with those of a treatment receiving $\mathrm{NoP}$ and a treatment receiving water-soluble mineral $\mathrm{P}$ [MinP, $\mathrm{Ca}\left(\mathrm{H}_{2} \mathrm{PO}_{4}\right)_{2} \cdot \mathrm{H}_{2} \mathrm{O}$ in aqueous solution]. For the purposes of methodological control, the fertilization effect of MinP was also studied using direct labeling (MinPdir). MinPdir was produced by labeling $\mathrm{Ca}\left(\mathrm{H}_{2} \mathrm{PO}_{4}\right)_{2} \cdot \mathrm{H}_{2} \mathrm{O}$ in aqueous solution with specific activity (SA) $40 \mathrm{kBq} \mathrm{mg} \mathrm{P}^{-1}$ and applied corresponding to $1.2 \mathrm{MBq} \mathrm{kg}^{-1}$ soil. All fertilizers were applied based on a total 
TABLE 3 | Chemical properties of the soil.

\begin{tabular}{|c|c|c|c|c|c|c|c|c|}
\hline $\begin{array}{l}\text { Organic } \\
\text { matter }^{\mathrm{a}}(\%)\end{array}$ & $\begin{array}{c}\text { Total Pb } \\
\left(\mathbf{m g ~ k g} \mathbf{~ k g}^{-1}\right)\end{array}$ & $\begin{array}{c}\mathrm{Po}^{\mathrm{b}} \\
\left(\mathrm{mg} \mathrm{kg}^{-1}\right)\end{array}$ & $\begin{array}{c}\text { P-ALc } \\
\left(\mathrm{mg} \mathrm{kg}^{-1}\right)\end{array}$ & $\begin{array}{c}\mathrm{K}-\mathrm{AL}^{\mathrm{c}} \\
\left(\mathrm{mg} \mathrm{kg} \mathbf{~ k g}^{-1}\right)\end{array}$ & $\begin{array}{c}M g-A L^{c} \\
\left(\mathrm{mg} \mathrm{kg}^{-1}\right)\end{array}$ & $\begin{array}{l}\text { Ca-ALc } \\
\left(g^{k} g^{-1}\right)\end{array}$ & $\begin{array}{l}O x-F e^{d} \\
\left(g k^{-1}\right)\end{array}$ & $\begin{array}{c}O x-A l^{d} \\
\left.\left(g_{k g}\right)^{-1}\right)\end{array}$ \\
\hline 4.5 & 1024 & 456 & 44 & 138 & 44 & $1.3-1.9$ & 4.8 & 1.9 \\
\hline
\end{tabular}

Po, organic $P$.

alncineration at $550^{\circ} \mathrm{C}$.

${ }^{b} \mathrm{By}$ ignition method after extraction with $6 \mathrm{M} \mathrm{H}_{2} \mathrm{SO}_{4}$ according to Møberg and Petersen (26). Colorimetric analysis according to Murphy and Riley (27).

${ }^{\circ}$ Extraction with $0.1 \mathrm{M}$ ammonium lactate and $0.4 \mathrm{M}$ acetic acid adjusted to pH 3.75 according to Egnér et al. (32), analyzed on ICP-OES.

${ }^{d}$ Extraction with $0.2 \mathrm{M}$ ammonium oxalate in oxalic acid according to van Reeuwijk (33), analyzed by ICP-OES.

$\mathrm{P}$ content equivalent to $30 \mathrm{mg} \mathrm{P} \mathrm{kg}^{-1}$ and mixed into the whole

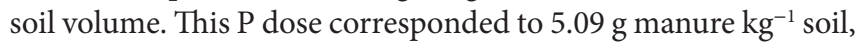
$1.48 \mathrm{~g}$ fish sludge $\mathrm{kg}^{-1}$ soil, $0.57 \mathrm{~g}$ meat bone meal kg-1 soil, and $1.76 \mathrm{~g}$ wood ash $\mathrm{kg}^{-1}$ soil. To study the response of the soil to $\mathrm{P}$ fertilization, unlabeled MinP was also applied at rates of 15 and $45 \mathrm{mg} \mathrm{P} \mathrm{kg}{ }^{-1}$ soil. At the same time, all pots received a P-free nutrient solution containing $75 \mathrm{mg} \mathrm{N}\left[\mathrm{Ca}\left(\mathrm{NO}_{3}\right)_{2} \cdot 4 \mathrm{H}_{2} \mathrm{O}\right], 75 \mathrm{mg} \mathrm{K}$ $\left(\mathrm{K}_{2} \mathrm{SO}_{4}\right), 15 \mathrm{mg}$ magnesium $\left(\mathrm{Mg} ; \mathrm{MgSO}_{4} \cdot 7 \mathrm{H}_{2} \mathrm{O}\right), 0.1 \mathrm{mg}$ molybdenum ( $\left.\mathrm{Mo} ; \mathrm{Na}_{2} \mathrm{MoO}_{4} \cdot 2 \mathrm{H}_{2} \mathrm{O}\right), 1 \mathrm{mg}$ zinc $\left(\mathrm{Zn} ; \mathrm{ZnSO}_{4} \cdot 7 \mathrm{H}_{2} \mathrm{O}\right)$, $1 \mathrm{mg} \mathrm{Fe}$ (Fe-chelate), $1 \mathrm{mg}$ boron $\left(\mathrm{B} ; \mathrm{H}_{3} \mathrm{BO}_{3}\right), 2 \mathrm{mg}$ copper $(\mathrm{Cu}$; $\left.\mathrm{CuSO}_{4} \cdot 5 \mathrm{H}_{2} \mathrm{O}\right)$, and $2 \mathrm{mg}$ manganese $\left(\mathrm{Mn} ; \mathrm{MnSO}_{4} \cdot \mathrm{H}_{2} \mathrm{O}\right)$ per $\mathrm{kg}$ soil. There were four replicates per treatment. Seven barley seeds (H. vulgare, var. Heder) were sown per pot and thinned out to five plants after germination. Seventeen days after setup of the experiment, when plants had developed three to four leaves, all pots were also given $75 \mathrm{mg} \mathrm{N}$ and $209 \mathrm{mg} \mathrm{K}$ as $\mathrm{KNO}_{3}$. All plants were watered with distilled water by weighing to $70 \%$ of WHC until germination, thereafter to $60 \%$ of WHC every 2 or 3 days, and daily toward the end of the experiment. Growing conditions in the greenhouse were set to $16 \mathrm{~h}$ photoperiod with artificial lights turning on when daylight $<20 \mathrm{klx}$. Atmospheric humidity and mean temperature were set to $65 \%$ and $20^{\circ} \mathrm{C}$ during the day and $72 \%$ and $16^{\circ} \mathrm{C}$ at night. Pot positions were randomized three times a week. Forty-four days after setup of the experiment, when the first awns were visible [development stage varying between Zadoks 35 and 50 (34)], aboveground biomass was harvested by cutting the plants with scissors at $2 \mathrm{~cm}$ above the soil surface. Plant material was dried at $55^{\circ} \mathrm{C}$ for $48 \mathrm{~h}, \mathrm{DM}$ production per pot was recorded and the plant material was milled in a Retsch ZM 200 mill $(\leq 0.2 \mathrm{~mm})$. For determination of $\mathrm{P}$ concentration in the plant tissue, $250 \mathrm{mg}$ were incinerated at $550^{\circ} \mathrm{C}$ for $3 \mathrm{~h}$ and extracted with $3 \mathrm{~mL}$ concentrated, hot $\mathrm{HNO}_{3}$ [adapted according to (22)]. The $\mathrm{P}$ in the diluted filtrate $(0.2 \mu \mathrm{m}$ pore size) was determined colorimetrically according to Ohno and Zibilske (35). The P uptake per kg soil was computed by multiplying DM production by plant tissue $\mathrm{P}$ concentration. The ${ }^{33} \mathrm{P}$ beta emissions in the labeling solutions and the extracts were measured in $1 \mathrm{~mL}$ sample after addition of $5 \mathrm{~mL}$ appropriate scintillation liquid (PerkinElmer Ultima Gold or PerkinElmer Ultima Gold AB) by liquid scintillation counting (TRI-CARB 2500 TR, liquid scintillation analyzer, Packard Instruments, Meriden, CT, USA) and corrected for radioactive decay back to the day when the soil was labeled. The $\mathrm{N}$ concentration in plant tissue was determined using a Thermo Electron FlashEA 1112 Automatic Elemental Analyser. Soil samples were taken in each pot and soil pH was measured in a solid-solution-ratio of 1:2.5 (v/v) in $\mathrm{H}_{2} \mathrm{O}$ after drying soil samples at $55^{\circ} \mathrm{C}$ and sieving at mesh width $\leq 2 \mathrm{~mm}$.

\section{Seed P Experiment}

An additional experiment was conducted to determine the contribution of barley seed $\mathrm{P}$ to $\mathrm{P}$ uptake in aboveground biomass in response to increasing fertilization rate when the indirect method was used $(22,36)$. Sand $(0.7-1.2 \mathrm{~mm})$ was washed in $2 \% \mathrm{HCl}$ before thorough rinsing with distilled $\mathrm{H}_{2} \mathrm{O}$. Afterward, the $\mathrm{pH}$ of the sand was 4.97 [solid-solution-ratio of 1:2.5 (v/v) in $\mathrm{H}_{2} \mathrm{O}$ ]. Portions of $1 \mathrm{~kg}$ sand DM were then fertilized with $0,7.5,15,22.5$ or $30 \mathrm{mg} \mathrm{P} \mathrm{kg}^{-1}$ sand. The $\mathrm{P}$ fertilizer $\left[\mathrm{Ca}\left(\mathrm{H}_{2} \mathrm{PO}_{4}\right)_{2} \cdot \mathrm{H}_{2} \mathrm{O}\right.$ in aqueous solution] was labeled with ${ }^{33} \mathrm{P}$. The pots received $720 \mathrm{kBq} \mathrm{kg}^{-1}$ sand with the fertilizer, i.e., the SA of the P fertilizer was 96,48 , 32 , and $24 \mathrm{kBq} \mathrm{mg}^{-1} \mathrm{P}$, respectively. The same P-free nutrient solution as given in the pot experiment was used. There were four replicates per treatment. Seven barley seeds were sown per pot and thinned out to five plants after germination. With five barley seeds, $0.71 \pm 0.08 \mathrm{mg} P$ were applied per kilogram of soil, as determined by the average weight of five barley seeds $(0.20 \pm 0.02 \mathrm{~g}$ $\left.\mathrm{DM} \mathrm{kg}^{-1}, n=20\right)$ and $\mathrm{P}$ concentration $\left(3.49 \pm 0.04 \mathrm{mg} \mathrm{P} \mathrm{g}^{-1} \mathrm{DM}\right.$, determined by colorimetric analysis after microwave digestion in concentrated $\mathrm{H}_{2} \mathrm{O}_{2}$ and $\left.\mathrm{HNO}_{3}, n=4\right)$. During the first 19 days, the plants were watered up to $130 \mathrm{~g} \mathrm{H}_{2} \mathrm{O} \mathrm{kg}$-1 sand, after which the water ratio was increased to $220 \mathrm{~g} \mathrm{H}_{2} \mathrm{O} \mathrm{kg}^{-1}$ sand. Plants were harvested by cutting with scissors at $2 \mathrm{~cm}$ above the sand surface 50 days after setup of the experiment when the first awns were visible (Zadoks 35-49). Plant material was analyzed in the same way as described for the pot experiment. During the seed P experiment, any isotopic dilution of the ${ }^{33} \mathrm{P}$ in the shoot was caused by seed $\mathrm{P}$, since this was the only non-labeled source. Therefore, this experiment allowed the $\mathrm{P}$ contribution from the seed and that from the fertilizer to be distinguished.

\section{Calculations for Pot and Seed $\mathbf{P}$ Experiment}

When labeled fertilizer was applied to the soil (direct method in pot study and seed $\mathrm{P}$ experiment), $\mathrm{P}$ derived from the fertilizer (Pdf fertilizer, $\mathrm{mg} \mathrm{P} \mathrm{kg}^{-1}$ soil) was calculated as

$$
\text { Pdf fertilizer }=\frac{\mathrm{SA}_{\text {plant }}}{\mathrm{SA}_{\text {fert }}} \times \mathrm{P}_{\text {uptake }} \mathrm{P}_{\mathrm{P}^{+}}
$$

where $\mathrm{SA}_{\text {plant }}\left(\mathrm{Bq} \mathrm{mg^{-1 }} \mathrm{P}\right)$ is the $\mathrm{SA}$ in the plant amended with the labeled fertilizer, $\mathrm{SA}_{\text {fert }}\left(\mathrm{Bq} \mathrm{mg}^{-1} \mathrm{P}\right)$ is the $\mathrm{SA}$ in the fertilizer, and $\mathrm{P}$ uptake $\mathrm{P}_{\mathrm{P}^{+}}\left(\mathrm{mg} \mathrm{P} \mathrm{kg} \mathrm{kg}^{-1}\right.$ soil) is the amount of $\mathrm{P}$ taken up by the fertilized plant in aboveground biomass. In the seed $\mathrm{P}$ experiment, $\mathrm{P}$ derived from the seed (Pdf seed) was calculated as the difference between P uptake and Pdf fertilizer. 
When the pool of plant-available $\mathrm{P}$ in the soil was labeled before application of an unlabeled fertilizer (indirect method), Pdf fertilizer was calculated as

$$
\text { Pdf fertilizer }=\text { P uptake }{ }_{\mathrm{P}^{+}}-\text {Pdf soil }_{\mathrm{P}^{+}}-\text {Pdf seed } \mathrm{P}_{\mathrm{P}^{+}}
$$

where Pdf soil $\mathrm{p}_{\mathrm{p}^{+}}$is the amount of P derived from the soil (mg $\mathrm{P} \mathrm{kg}^{-1}$ soil) in the fertilized plant, which was calculated as

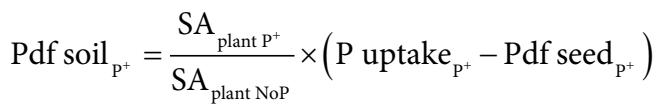

where $\mathrm{SA}_{\text {int }}\left(\mathrm{Bq} \mathrm{mg}^{-1} \mathrm{P}\right)$ is the $\mathrm{SA}$ in the fertilized plants, $\mathrm{SA}_{\text {plant NoP }}\left(\mathrm{Bq} \mathrm{mg} \mathrm{m}^{-1} \mathrm{P}\right)$ is the average $\mathrm{SA}$ in the plants receiving NoP with P uptake corrected for Pdf seed, and Pdf seed ${ }_{\mathrm{P}^{+}}$is $\mathrm{P}$ derived from the seed ( $\mathrm{mg} \mathrm{P} \mathrm{kg}^{-1}$ soil) in the fertilized plants, which was calculated from the seed $\mathrm{P}$ experiment as follows:

$$
\text { Pdf seed }{\mathrm{\textrm {P } ^ { + }}}=a \times \mathrm{P} \text { uptake }_{\mathrm{P}^{+}}+b
$$

where $a$ and $b$ are the slope and intercept of the function presented in Figure 1.

Moreover, fertilizer recovery (\%) was calculated as the ratio between Pdf fertilizer and the amount of $\mathrm{P}$ applied with the fertilizer ( $\mathrm{P}$ fert, $\mathrm{mg} \mathrm{P} \mathrm{kg}^{-1}$ ):

$$
\text { Fertilizer recovery }=\frac{\text { Pdf fertilizer }}{P \text { fert }} \times 100
$$

Relative agronomic efficiency (RAE, \%) was calculated as the ratio between the fertilizer recovery of each secondary resource $\left(\mathrm{P}^{+}\right)$and the fertilizer recovery of MinP applied at the same rate (30 $\mathrm{mg} \mathrm{P} \mathrm{kg}^{-1}$ soil) as the secondary resource:

$$
\text { Relative agronomic efficiency }=\frac{\text { Fertilizer recovery }_{\mathrm{P}^{+}}}{\text {Fertilizer recovery }} \text { MinP }_{100}
$$

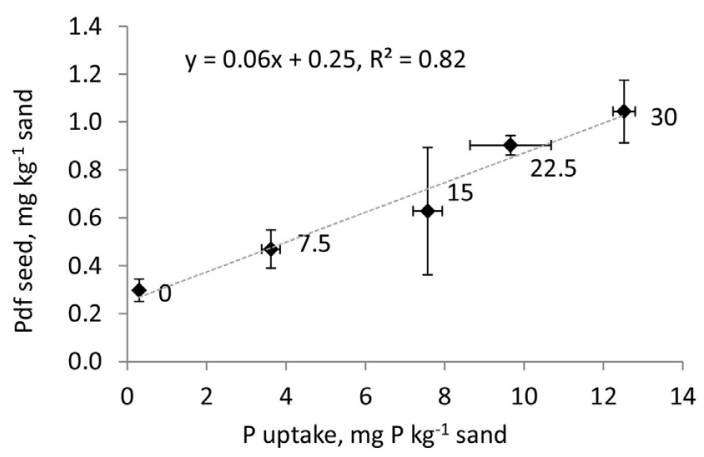

FIGURE 1 | Relationship between P uptake in aboveground biomass ( $\mathrm{mg} \mathrm{P} \mathrm{kg}^{-1}$ sand) and $\mathbf{P}$ derived from the seed (Pdf seed, $\mathrm{mg} \mathrm{P} \mathrm{kg}^{-1}$ sand) for barley grown on sand and fertilized with increasing rates of MinP labeled with ${ }^{33} \mathrm{P}\left(0,7.5,15,22.5\right.$, and $30 \mathrm{mg} \mathrm{P} \mathrm{kg}^{-1}$ sand as indicated next to the experimental points). Error bars represent $\mathrm{SD}$ of the four replicates.

\section{Incubation Experiment}

\section{Setup of the Incubation Experiment}

In parallel, soil-fertilizer incubations were conducted to study physicochemical and microbial soil processes affected by the secondary resources in comparison with $\mathrm{MinP}$ and $\mathrm{NoP}$ on the unlimed and limed soil. Again, the soil was pre-incubated with distilled $\mathrm{H}_{2} \mathrm{O}$ at $40 \%$ of WHC to minimize a microbial boost during setup of the experiments. Three weeks after pre-incubation, aliquots of $1.2 \mathrm{~kg}$ soil were mixed with ${ }^{33} \mathrm{P}$ corresponding to $5.2 \mathrm{MBq} \mathrm{kg}{ }^{-1}$ soil that was added after dilution in $\mathrm{H}_{2} \mathrm{O}$ by $10 \mathrm{~mL} \mathrm{~kg}^{-1}$ soil for an incubation experiment with soil $\mathrm{P}$ labeling (indirect method). As for the pot experiment, the soil was kept in a controlled environment to reach near-equilibrium conditions for ${ }^{31} \mathrm{P}$ and ${ }^{33} \mathrm{P}$ for 10 days. A soil-fertilizer incubation experiment with no soil or fertilizer P labeling (termed unlabeled incubation) was also set up to determine isotopically exchangeable $P$ as affected by $\mathrm{P}$ fertilizer (method described below). During the setup of both incubations, aliquots of $300 \mathrm{~g}$ soil were watered to $50 \%$ of WHC and mixed with fertilizer corresponding to $30 \mathrm{mg} \mathrm{P} \mathrm{kg}^{-1}$ soil, but in contrast to the pot experiment, no P-free nutrient solution was added. Sub-aliquots of $100 \mathrm{~g}$ soil corresponding to three time points were placed in sealed plastic bags and kept in the dark under identical experimental conditions as in the pot experiment until analysis. There were four replicates per treatment. The effect of fertilizers on soil $\mathrm{pH}$ was studied after 7, 21, and 42 days in the incubation experiment with soil $\mathrm{P}$ labeling as described above.

\section{P Concentration in Soil Solution and Isotopically Exchangeable $\mathrm{P}$}

The effects of fertilizers on the $\mathrm{P}$ concentration in the soil solution $\left(C_{\mathrm{P}}, \mathrm{mg} \mathrm{P} \mathrm{L}^{-1}\right)$ and isotopically exchangeable $\mathrm{P}\left(E_{1 \mathrm{~min}}\right.$, in mg $\mathrm{P} \mathrm{kg}^{-1}$ ) (37) were determined after 21 days in soil sampled in the unlabeled incubation experiment. The $E_{1 \min }$ comprises the $\mathrm{Pi}$ in the soil solution and $\mathrm{Pi}$ adsorbed to soil particles, which is exchangeable within the first minute of isotopic exchange kinetics (21). Incubated soil samples were dried at $40^{\circ} \mathrm{C}$ before extraction of $10 \mathrm{~g}$ soil in $99 \mathrm{~mL} \mathrm{H}_{2} \mathrm{O}$ by end-over-end shaking. Isotopic exchange kinetics analyses were carried out after $16 \mathrm{~h}$ of shaking based on the assumption that steady-state equilibrium was reached, i.e., that $C_{\mathrm{P}}$ was constant. The suspensions were then stirred at $300 \mathrm{rpm}$ on a magnetic plate when $1 \mathrm{~mL}$ carrier-free ${ }^{33} \mathrm{P}$ solution with a known amount of radioactivity was added to result in $R=600-900 \mathrm{~Bq} \mathrm{~mL}^{-1}$ in the sample. The soil:solution ratio was then $1: 10$. The suspensions were sampled with plastic syringes at $1,4,10,30,60$, and $90 \mathrm{~min}$ after ${ }^{33} \mathrm{P}$ addition $(t)$. The remaining ${ }^{33} \mathrm{P}$ in the filtrate $[r(t), 0.2 \mu \mathrm{m}$ pore size $]$ was determined using scintillation counting as described above. After the last sampling, $C_{\mathrm{P}}$ was determined colorimetrically (35). The $E_{1 \mathrm{~min}}$ was calculated based on the assumption that $R$ was evenly diluted with all inorganic $\mathrm{P}$ fractions having the same isotopic composition, according to

$$
E_{1 \min }=10 \times C_{\mathrm{P}} \times \frac{R}{r(1)}
$$




$$
\frac{r(t)}{R}=m \times\left[t+(m)^{\frac{1}{n}}\right]^{-n}+\frac{10 \times C_{\mathrm{P}}}{\mathrm{Pi}}
$$

where $\mathrm{Pi}$ is the sum of $\mathrm{Pi}$ in the experimental soil (Total P minus Po; Table 3) and the fertilization rate 0 or $30 \mathrm{mg} \mathrm{P} \mathrm{kg}^{-1}$. The isotopic dilution parameters $m$ and $n$ were calculated from a non-linear regression between $r(t) / R$ and $t$ before statistical refinement. The isotopic dilution parameter $m$ is a measure of the remaining radioactivity in the solution after $1 \mathrm{~min}$ and $n$ is a measure of how fast the radioactivity is disappearing from the solution.

\section{Resin-Extractable P}

The effects of fertilizers on resin-extractable $\mathrm{P}$ (Resin $\mathrm{P}$ ) were studied after 7 and 21 days on soil sampled in the indirectly labeled incubation experiment. Moist samples equaling $2 \mathrm{~g}$ soil DM were extracted in $30 \mathrm{~mL} \mathrm{H}_{2} \mathrm{O}$ upon horizontal shaking at $160 \mathrm{rec} \mathrm{min}^{-1}$ for $16 \mathrm{~h}$ with simultaneous adsorption to anionexchange resin membranes (BDH $551642 \mathrm{~S}, 6 \mathrm{~cm} \times 2 \mathrm{~cm}$ ) that had been shaken in advance twice in $0.5 \mathrm{M} \mathrm{NaHCO}_{3}$ for $1 \mathrm{~h}$. The $\mathrm{P}$ adsorbed to resin membranes was extracted by $0.1 \mathrm{M} \mathrm{NaCl} / 0.1 \mathrm{M}$ $\mathrm{HCl}$. The $\mathrm{P}$ concentrations and radioactivity were determined as described above. The indirect labeling allowed estimation of the fraction of Resin P deriving from the fertilizer (Pdff Resin P, \%) according to

$$
\text { Pdff Resin } \mathrm{P}=\left(1-\frac{\mathrm{SA}_{\mathrm{p}^{+}}}{\mathrm{SA}_{\mathrm{NoP}}}\right) \times 100
$$

where $\mathrm{SA}_{\mathrm{P}^{+}}\left(\mathrm{Bq} \mathrm{mg} \mathrm{g}^{-1} \mathrm{P}\right)$ is the $\mathrm{SA}$ in the soil amended with fertilizer and $\mathrm{SA}_{\mathrm{NoP}}\left(\mathrm{Bq} \mathrm{mg}^{-1} \mathrm{P}\right)$ is the $\mathrm{SA}$ in the soil receiving $\mathrm{NoP}$.

\section{Microbial P}

The effects of fertilizer on $\mathrm{P}$ in microbial biomass (Pmic) were estimated after 7 and 21 days in the indirectly labeled incubation experiment as the difference between extracted $\mathrm{P}$ with simultaneous adsorption to anion-exchange resin membranes from fumigated and non-fumigated soil samples (Resin P). For the fumigation extraction, moist soil equaling $2 \mathrm{~g}$ soil $\mathrm{DM}$ was extracted in $30 \mathrm{~mL} \mathrm{H}_{2} \mathrm{O}$ with $1 \mathrm{~mL}$ hexanol for $16 \mathrm{~h}$. As a methodological control, $2 \mathrm{~g}$ soil DM were extracted in $30 \mathrm{~mL} \mathrm{H} \mathrm{H}_{2} \mathrm{O}$ using anion-exchange resin membranes after addition of a $\mathrm{P}$ spike of $10 \mu \mathrm{g} \mathrm{P} \mathrm{g}^{-1}$ soil for $16 \mathrm{~h}$. The test showed that released P was effectively sorbed to the anion-exchange resin membranes, and it was not necessary to correct microbial biomass $P$ for sorption to soil of $\mathrm{P}$ released during the fumigation-extraction.

\section{Statistical Analysis}

Equation 8 was adjusted using a non-linear procedure. Two-way ANOVA was applied to test the effect of the factors fertilizer treatment and $\mathrm{pH}$ level and their interaction on parameters studied in the pot and incubation experiment. Data sets were also analyzed using one-way ANOVA within the unlimed and the limed soil, respectively. Directly labeled treatments were excluded from the variance analyses and presented separately, including the SD of four replicates. Analyzed data were checked for normal distribution (normal quantile plots) and homogeneity of variance (residual versus fitted plots), and log transformed if indicated. For pair-wise comparisons, Tukey's HSD test or $t$-tests were used at significance level $\alpha=0.05$. Moreover, simple linear regressions were run with selected parameters of the pot experiment as response variables and the parameters of the incubation experiment as explanatory variables, which were averaged over the four replicates. All statistical analyses were performed with JMP Pro 11.1.1 (38).

\section{RESULTS}

\section{P Concentration, Dry Matter Production, and Total P Uptake}

There was a clear response of barley to $\mathrm{P}$ application on the experimental soil, as shown by linear increases in $\mathrm{P}$ uptake in aboveground biomass as a function MinP application rate $(0,15$, 30 , and $45 \mathrm{mg} \mathrm{P} \mathrm{kg}^{-1}$ soil) on both the unlimed and limed soil. The slopes of the response curves for the two soils were not significantly different $(p=0.75)$, while the intercept was significantly higher on the limed than on the unlimed soil $(p<0.01)$ (see Supplementary Material). Phosphorus concentration in plant biomass ranged from 1.6 to $2.2 \mathrm{mg} \mathrm{P} \mathrm{g}^{-1} \mathrm{DM}$. The $\mathrm{P}$ nutrition index for temperate grasses, calculated according to Liebisch et al. (39), clearly indicated P limitation in all fertilizer treatments (results not shown). Nitrogen concentrations (3.0-4.4 g $100 \mathrm{~g}^{-1}$ $\mathrm{DM}$, results are not shown) were clearly above critical levels in temperate grasses as calculated according to Lemaire et al. (40), and observed differences between fertilizer treatments were therefore ascribed to $\mathrm{P}$ fertilization effects rather than $\mathrm{N}$ fertilization effects.

All secondary resources resulted in equally high $\mathrm{P}$ concentration as MinP on both soils except manure, which resulted in significantly lower P concentration than MinP on the limed soil. Aboveground DM production ranged from 3.5 to $5.2 \mathrm{~g} \mathrm{~kg}^{-1}$ soil and was equally high on the unlimed and limed soil (Table 4). None of the secondary resources increased DM compared with NoP on either soil, while MinP significantly increased DM compared with NoP on both soils. Phosphorus uptake in aboveground biomass ranged from 5.7 to $10.8 \mathrm{mg} \mathrm{P} \mathrm{kg}^{-1}$ soil and was as result of slightly higher $\mathrm{P}$ concentration on the limed soil on average $0.5 \mathrm{mg} \mathrm{P} \mathrm{kg}^{-1}$ soil greater on the limed than on the unlimed soil. All secondary resources resulted in significantly lower $\mathrm{P}$ uptake than MinP on both soils, except fish sludge, which resulted in equally large P uptake as MinP on the limed soil (Table 4).

\section{P Uptake from Different Sources}

Phosphorus derived from soil was the most important P source for barley plants with all fertilizer treatments on both soils (Figure 2). All treatments resulted in equally large Pdf soil, except manure, which resulted in significantly smaller Pdf soil than all other treatments on the unlimed soil and in smaller Pdf soil than NoP on the limed soil.

Phosphorus derived from fertilizer was significantly smaller after application of secondary resources than after MinP on both soils (Figure 2). Only manure resulted in equally large Pdf fertilizer as MinP on the limed soil. Fish sludge and wood ash 
TABLE 4 | Aboveground dry matter production (DM), P concentration and P uptake in aboveground biomass, P derived from fertilizer (Pdf fertilizer, \%), fertilizer recovery $(\%)$, and relative agronomic efficiency (RAE, \%) as an effect of different fertilizer treatments on unlimed and limed soil.

\begin{tabular}{|c|c|c|c|c|c|c|c|c|c|c|c|c|}
\hline \multirow{2}{*}{$\begin{array}{l}\text { Treatment } \\
\text { Unlimed soil }\end{array}$} & \multicolumn{2}{|c|}{$\begin{array}{l}\text { Dry matter } \\
\left(g^{\circ} \mathrm{DM} \mathrm{kg} \mathbf{~ k}^{-1}\right)\end{array}$} & \multicolumn{2}{|c|}{$\begin{array}{l}\text { P concentration } \\
\left.\text { (mg P g } \mathbf{~ g M}^{-1} \mathrm{DM}\right)\end{array}$} & \multicolumn{2}{|c|}{$\begin{array}{c}\text { P uptake } \\
\text { (mg P kg } \text { kgil) }^{-1} \text { soil }\end{array}$} & \multicolumn{2}{|c|}{$\begin{array}{l}\text { Pdf fertilizer } \\
\qquad(\%)\end{array}$} & \multicolumn{2}{|c|}{$\begin{array}{l}\text { Fertilizer recovery } \\
\qquad(\%)\end{array}$} & \multicolumn{2}{|c|}{$\begin{array}{l}\text { RAE } \\
(\%)\end{array}$} \\
\hline & & & & & & & & & & & & \\
\hline NoP & 3.5 & $b$ & 1.6 & $\mathrm{~b}$ & 5.7 & c & & & & & & \\
\hline MinP & 5.2 & $a$ & 1.9 & $\mathrm{a}$ & 10.2 & a & 42.4 & $a$ & 14.4 & a & $100^{\mathrm{a}}$ & \\
\hline Manure & 4.1 & $\mathrm{~b}$ & 1.7 & $a b$ & 7.0 & $\mathrm{bc}$ & 40.2 & $a b$ & 8.8 & $\mathrm{~b}$ & 60.9 & $\mathrm{a}$ \\
\hline Fish sludge & 4.0 & $b$ & 1.9 & a & 7.5 & $\mathrm{~b}$ & 29.0 & $\mathrm{bc}$ & 6.9 & $b$ & 47.8 & $\mathrm{a}$ \\
\hline Meat bone meal & 3.5 & $\mathrm{~b}$ & 1.8 & $a b$ & 6.4 & $\mathrm{bc}$ & 11.2 & $d$ & 2.3 & $\mathrm{C}$ & 16.0 & $b$ \\
\hline Wood ash & 3.7 & $\mathrm{~b}$ & 1.9 & a & 7.1 & $\mathrm{bc}$ & 23.6 & $\mathrm{~cd}$ & 5.6 & $\mathrm{bc}$ & 38.7 & $a b$ \\
\hline SEM & 0.2 & & 0.1 & & 0.4 & & 2.9 & & 0.9 & & 5.6 & \\
\hline HSD & 0.8 & & 0.3 & & 1.6 & & 12.8 & & 4.0 & & 23.4 & \\
\hline MinPdir & 5.0 & & & & & & 36 & & & & n.d. & \\
\hline \multicolumn{13}{|l|}{ Limed soil } \\
\hline $\mathrm{NoP}$ & 3.5 & $\mathrm{~b}$ & 1.8 & $a b$ & 6.4 & $b$ & & & & & & \\
\hline MinP & 5.0 & $\mathrm{a}$ & 2.2 & $\mathrm{a}$ & 10.8 & $\mathrm{a}$ & 45.1 & $a$ & 16.3 & $\mathrm{a}$ & $100^{\mathrm{a}}$ & \\
\hline Manure & 4.6 & $a b$ & 1.8 & $b$ & 8.3 & $\mathrm{~b}$ & 41.0 & a & 10.7 & $\mathrm{~b}$ & 65.7 & a \\
\hline Fish sludge & 4.5 & $a b$ & 1.9 & $a b$ & 8.7 & $a b$ & 28.6 & $\mathrm{~b}$ & 7.9 & bc & 48.6 & $a b$ \\
\hline Meat bone meal ${ }^{b}$ & 3.7 & $b$ & 1.9 & $a b$ & 7.0 & $b$ & 18.8 & $b$ & 4.4 & c & 26.9 & $b$ \\
\hline Wood ash & 3.9 & $a b$ & 1.9 & $a b$ & 7.6 & $\mathrm{~b}$ & 28.1 & $\mathrm{~b}$ & 7.1 & $\mathrm{bc}$ & 43.8 & $a b$ \\
\hline SEM & 0.3 & & 0.1 & & 0.5 & & 2.6 & & 1.2 & & 6.7 & \\
\hline HSD & 1.1 & & 0.4 & & 2.4 & & 11.3 & & 5.1 & & 28.6 & \\
\hline MinPdir & $4 . \subseteq$ & & & & & & 33 & & & & n.d. & \\
\hline \multicolumn{13}{|c|}{ Two-way ANOVA, source of variation } \\
\hline Treatment & $* \star \star$ & & *** & & $* \star * *$ & & 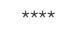 & & *** & & 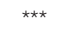 & \\
\hline Soil & n.s. & & * & & ** & & n.s. & & * & & n.s. & \\
\hline Treatment $\times$ soil & n.s. & & n.s. & & n.s. & & n.s. & & n.s. & & n.s. & \\
\hline
\end{tabular}

SEM, pooled SEM; HSD, Tukey's honest significant difference at each pH level, where values followed by the same letter are not significantly different; n.s., not significant, n.d., not determined. For MinPdir mean $\pm S D$ of four replicates.

${ }^{*},{ }^{* *}$, and ${ }^{* * *}$ significant at $p<0.05,0.01$, and 0.001 probability level, respectively.

${ }^{a}$ By definition set to $100 \%$.

${ }^{b}$ Only three observations due to Pdf fertilizer $<0$ for one replicate.

resulted in equally large Pdf fertilizer as manure, while meat bone meal resulted in significantly smaller Pdf fertilizer than manure on both soils. The Pdf fertilizer accounted for $40-44 \%$ of P uptake in plants after application of MinP or manure, and in significantly smaller fractions after application of the other secondary resources compared with MinP (Table 4). Fertilizer recovery was 14-16\% of applied MinP and was significantly lower after application of all secondary resources on both soils. The RAE decreased in the order manure $\geq$ fish sludge $\geq$ wood ash $\geq$ meat bone meal on both soils, but only meat bone meal resulted in significantly lower RAE than manure. Fish sludge and wood ash resulted in equally high RAE as manure.

The MinP treatment resulted in significantly smaller Pdf soil than MinPdir, the average difference being $1 \mathrm{mg} \mathrm{P} \mathrm{kg}^{-1}$, and in significantly larger Pdf fertilizer than MinPdir, the difference being $0.7 \mathrm{mg} \mathrm{P} \mathrm{kg}{ }^{-1}$ (two-sided $t$-tests over both soils, $n=8$ ). The variability between replicates was also generally lower for MinPdir than for MinP and all other treatments.

The Pdf soil and Pdf fertilizer were corrected for Pdf seed as estimated from the relationship between P uptake and Pdf seed studied in the seed $\mathrm{P}$ experiment (Figure 1). In the seed $\mathrm{P}$ experiment, Pdf seed significantly increased with increasing $\mathrm{P}$ fertilization rate. The $\mathrm{P}$ uptake by the highest $\mathrm{P}$ fertilization rate $\left(1.04 \pm 0.15 \mathrm{mg} \mathrm{P} \mathrm{kg}^{-1}\right)$ in aboveground biomass was higher than the average amount of $\mathrm{P}$ applied with the seeds (estimated to be $0.71 \pm 0.08 \mathrm{mg} \mathrm{P}^{-1}$ ). With $a$ and $b$ from Figure 1, $0.65-0.95 \mathrm{mg} \mathrm{P}$ pot $^{-1}$ in aboveground biomass was estimated to derive from seeds, representing $8.6-10.7 \%$ of $\mathrm{P}$ uptake in the pot experiment. The ranking of Pdf soil and fertilizer among treatments did not change when not corrected for Pdf seed (see Supplementary Material), emphasizing the low importance of Pdf seed in the present study.

\section{Physicochemical and Microbial Soil Processes}

On the unlimed soil, all fertilizers initially increased available $\mathrm{P}$ over NoP in the incubation experiment, as reflected by Resin $\mathrm{P}$, measured 7 days after application (Table 5). Seven days after fertilizer application, Pdf fertilizer in the Resin P pool ranged from 25 to $38 \%$, but there were no significant differences between treatments. Twenty-one days after application, Resin P was on average $4.6 \mathrm{mg} \mathrm{P} \mathrm{kg}^{-1}$ soil lower than 7 days after fertilizer application (two-sided $t$-test over both time points, $n=48$ ), and only MinP resulted in higher Resin $\mathrm{P}$ than NoP. The Pdf fertilizer in the Resin P pool ranged from 19 to $52 \%$, again without significant differences between treatments. Twenty-one days after application, 

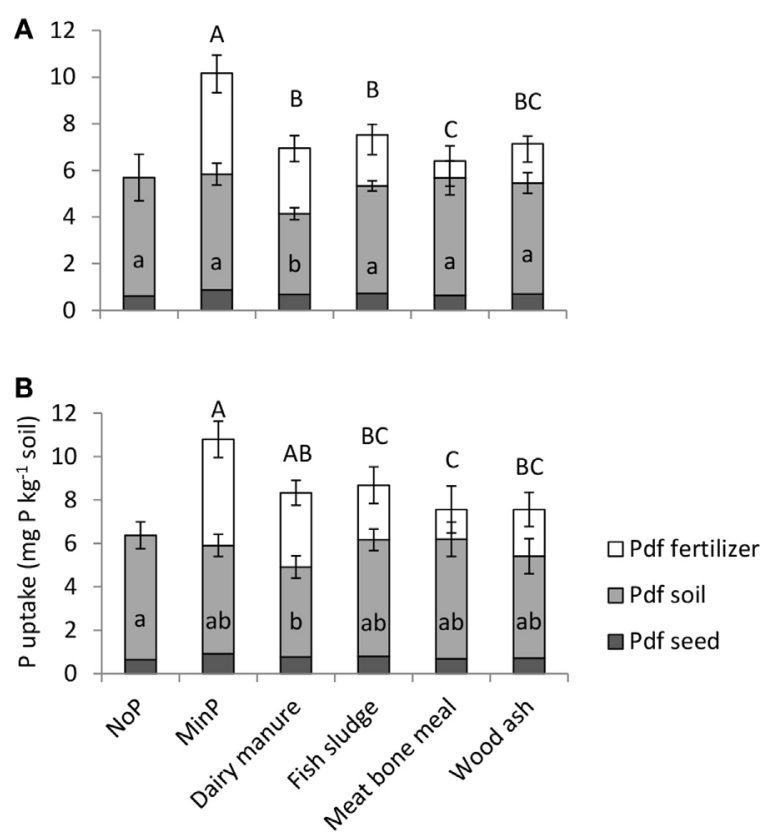

\begin{tabular}{|c|c|c|c|}
\hline & Pdf fertilizer & Pdf soil & Pdf seed \\
\hline \multicolumn{4}{|c|}{ Two-way ANOVA, source of variation } \\
\hline Treatment & $* * *$ & $* * *$ & $* * *$ \\
\hline Soil & * & * & $* *$ \\
\hline Treatment $x$ Soil & n.s. & n.s. & n.s. \\
\hline
\end{tabular}

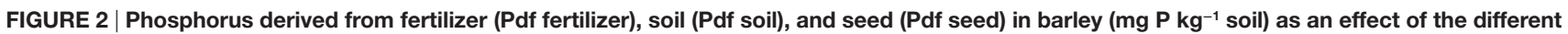
fertilizer treatments on (A) unlimed soil and (B) limed soil. Error bars represent the SD within each treatment. Letters indicate significant differences between treatments according to Tukey's test (one-way ANOVA for each soil); uppercase letters refer to Pdf fertilizer and lowercase letters to Pdf soil. On the unlimed soil, data on Pdf soil were log transformed for the statistical analysis. On the limed soil, for Pdf fertilizer of meat bone meal, only three observations were considered. *, **, and ${ }^{* \star *}$ significant at $p<0.05,0.01$, and 0.001 probability level, respectively.

all secondary resources increased $C_{\mathrm{P}}$ over NoP and resulted in equally high $E_{1 \min }$ as MinP.

On the limed soil, meat bone meal and fish sludge did not increase available $\mathrm{P}$ over NoP as reflected by $C_{\mathrm{P}}, E_{1 \mathrm{~min}}$, and Resin $\mathrm{P}$ at any time point. Wood ash did not increase Resin $\mathrm{P}$ over NoP at any time point on the limed soil, but resulted in equally high $C_{\mathrm{P}}$ and $E_{1 \min }$ as MinP. Seven days after fertilizer application, there were no differences in Pdf fertilizer in the Resin P pool between fertilizer treatments, with values ranging from 29 to $49 \%$. Twenty-one days after fertilizer application, meat bone meal was the only secondary resource that resulted in significantly lower Pdf fertilizer in the resin-extractable P pool (12\%) than MinP (41\%).

In the pot experiment, wood ash increased soil $\mathrm{pH}$ compared with NoP on both soils and meat bone meal resulted in significantly lower soil $\mathrm{pH}$ than NoP on the limed soil, while the other fertilizers had no significant effect on soil $\mathrm{pH}$ compared with NoP in the pot experiment (Table 5). In the incubation experiment, there were no differences in soil $\mathrm{pH}$ between the three time points, but soil $\mathrm{pH}$ was generally 0.4 and $0.2 \mathrm{pH}$ units lower than in the pot experiment on the unlimed and limed soil, respectively. In the incubation experiment, wood ash resulted in significantly higher soil $\mathrm{pH}$ than NoP on both soils, and the effects of fertilizer treatments generally followed a similar pattern as in the pot experiment. The results are therefore not shown.

Phosphorus uptake in microbial biomass (Table 5) was of the same order of magnitude as P uptake in plants (Table 4). It was generally higher on the limed than on the unlimed soil, the average difference being $8.4 \mathrm{mg} \mathrm{P} \mathrm{kg}^{-1}$ soil at 7 days and $3.1 \mathrm{mg} \mathrm{P} \mathrm{kg}{ }^{-1}$ soil at 21 days after fertilizer application. On the unlimed soil, there were no differences in Pmic between treatments, except an increase over NoP following meat bone meal application 21 days after fertilizer application. On the limed soil at 7 days after fertilizer application, only MinP had significantly increased Pmic over NoP. However, this effect was transient, as 21 days after fertilizer application Pmic of MinP was significantly lower than at 7 days after fertilizer application, and MinP and meat bone meal resulted in equally low Pmic as NoP. In contrast, manure and fish sludge had significantly increased Pmic over NoP.

\section{Drivers of P Uptake by Barley}

Phosphorus uptake by barley was best explained by the solubility of inorganic $\mathrm{P}$ in fertilizers, whereas additional effects of fertilizers on physicochemical and microbial soil processes were of little overall importance. This is shown by linear positive relationships between $\mathrm{P}$ uptake in barley and the $\mathrm{H}_{2} \mathrm{O}+\mathrm{NaHCO}_{3}$-soluble inorganic $\mathrm{P}(\mathrm{Pi})$ fraction in fertilizers and linear negative relationships between $\mathrm{P}$ uptake and the $\mathrm{HCl}$-soluble Pi fraction in fertilizers on both soils (Figure 3; Table 6). According to the sequential fractionation based on Hedley et al. (41), the $\mathrm{H}_{2} \mathrm{O}+\mathrm{NaHCO}_{3}$-soluble $\mathrm{Pi}$ fraction is operationally defined as readily available and labile $\mathrm{Pi}$, while the $\mathrm{HCl}$-soluble $\mathrm{Pi}$ fraction is defined as the slowly soluble $\mathrm{Ca}-\mathrm{P}$ fraction. Phosphorus uptake by barley could further be explained by $C_{\mathrm{P}}, m$, and Resin P measured 21 days after fertilizer application on both soils, which all represent measures for the 
TABLE 5 | pH measured in the pot experiment after harvest, $\boldsymbol{C}_{\mathrm{P}}=\mathrm{P}$ concentration in the soil solution, $\boldsymbol{m}$ and $\boldsymbol{n}=$ isotopic dilution parameters,

$E_{1 \text { min }}=$ isotopically exchangeable $\mathbf{P}$ within $1 \mathrm{~min}$, Resin $\mathbf{P}=$ resin-extractable $\mathbf{P}, \mathrm{Pdff}$ Resin $=\mathrm{P}$ derived from the fertilizer in the resin-extractable $\mathbf{P}$ pool (\%), and Pmic = microbial P 7 and 21 days after fertilizer application as an effect of different fertilizer treatments on unlimed and limed soil.

\begin{tabular}{|c|c|c|c|c|c|c|c|c|c|c|c|c|c|c|c|c|c|c|c|c|c|c|}
\hline \multirow{2}{*}{$\begin{array}{l}\text { Treatment } \\
\text { Unlimed soil }\end{array}$} & \multicolumn{2}{|c|}{$\mathrm{pH}$} & \multicolumn{2}{|c|}{$\begin{array}{c}\mathrm{C}_{\mathrm{P}^{\mathrm{a}}} \\
\text { Day } 21 \\
\left(\mathrm{mg} \mathrm{P} \mathrm{L}^{-1}\right)\end{array}$} & \multicolumn{2}{|c|}{$\begin{array}{c}m \\
\text { Day } 21\end{array}$} & \multicolumn{2}{|c|}{$\begin{array}{c}n \\
\text { Day } 21\end{array}$} & \multicolumn{2}{|c|}{$\begin{array}{c}E_{1 \min } \\
\text { Day } 21 \\
\left(\mathrm{mg} \mathrm{P}^{\mathrm{P}} \mathbf{k g}^{-1}\right)\end{array}$} & \multicolumn{2}{|c|}{$\begin{array}{c}\text { Resin P } \\
\text { Day } 7 \\
\left(\mathbf{m g ~ P ~ k g}{ }^{-1}\right)\end{array}$} & \multicolumn{2}{|c|}{$\begin{array}{c}\text { Resin Pa } \\
\text { Day } 21 \\
\left(\mathbf{m g ~ P ~ k g}^{-1}\right)\end{array}$} & \multicolumn{2}{|c|}{$\begin{array}{c}\text { Pdff Resin } \\
\text { Day } 7 \\
(\%)\end{array}$} & \multicolumn{2}{|c|}{$\begin{array}{c}\text { Pdff Resin } \\
\text { Day } 21 \\
(\%)\end{array}$} & \multicolumn{2}{|c|}{$\begin{array}{c}\text { Pmic }^{\mathrm{d}} \\
\text { Day } 7 \\
\left(\mathrm{mg} \mathrm{P}^{\mathrm{P}} \mathbf{~ g}^{-1}\right)\end{array}$} & \multicolumn{2}{|c|}{$\begin{array}{c}\text { Pmic } \\
\text { Day } 21 \\
\left(\mathrm{mg} \mathrm{P} \mathrm{kg}^{-1}\right)\end{array}$} \\
\hline & & & & & & & & & & & & & & & & & & & & & & \\
\hline NoP & 5.51 & bc & 0.09 & c & 0.27 & $a b$ & 0.40 & a & 3.3 & $b$ & 12.5 & $b$ & 10.1 & $\mathrm{~b}$ & & & & & 2.8 & n.s. & 6.2 & $\mathrm{bc}$ \\
\hline MinP & 5.49 & $c$ & 0.15 & $\mathrm{a}$ & 0.32 & a & 0.38 & $b$ & 4.8 & a & 21.6 & a & 25.2 & a & $38^{\mathrm{b}}$ & n.s. & $52^{\mathrm{b}}$ & n.s. & $3.7^{b}$ & n.s. & $3.6^{b}$ & $c$ \\
\hline Manure & 5.58 & $b$ & 0.13 & $a b$ & 0.29 & $a b$ & 0.39 & $a b$ & 4.6 & $\mathrm{a}$ & 23.7 & a & 13.9 & $b$ & 32 & n.s. & 38 & n.s. & 6.4 & n.s. & 9.7 & $a b$ \\
\hline Fish sludge & 5.45 & $\mathrm{C}$ & 0.12 & $b$ & 0.27 & $a b$ & 0.39 & $a b$ & 4.4 & $a b$ & 19.1 & $\mathrm{a}$ & 16.6 & $a b$ & $37^{b}$ & n.s. & 30 & n.s. & 5.8 & n.s. & 3.0 & $\mathrm{C}$ \\
\hline Meat bone meal & 5.44 & $\mathrm{C}$ & 0.12 & $\mathrm{~b}$ & 0.27 & $a b$ & 0.39 & $a b$ & 4.5 & $\mathrm{a}$ & 21.5 & a & 10.1 & $b$ & 25 & n.s. & 19 & n.s. & & & 9.9 & $\mathrm{a}$ \\
\hline Wood ash & 5.73 & a & 0.12 & $b$ & 0.26 & $b$ & 0.39 & $a b$ & 4.4 & $a b$ & 19.1 & $\mathrm{a}$ & 13.9 & $b$ & 30 & n.s. & 40 & n.s. & 9.2 & n.s. & 5.0 & c \\
\hline SEM & 0.02 & & 0.01 & & 0.01 & & 0.00 & & 0.3 & & 1.1 & & 2.2 & & 7 & & 7 & & 1.6 & & 0.8 & \\
\hline HSD & 0.09 & & 0.03 & & 0.05 & & 0.02 & & 1.2 & & 4.7 & & 9.9 & & 35 & & 35 & & 7.0 & & 3.7 & \\
\hline \multicolumn{23}{|l|}{ Limed soil } \\
\hline $\mathrm{NoP}$ & 6.25 & bc & 0.08 & $b$ & 0.23 & bc & 0.37 & $\mathrm{a}$ & 3.5 & $\mathrm{C}$ & 10.3 & $\mathrm{C}$ & 11.8 & $\mathrm{~b}$ & & & & & 9.1 & $\mathrm{bc}$ & 6.8 & $\mathrm{C}$ \\
\hline MinP & 6.23 & bcd & 0.15 & $\mathrm{a}$ & 0.27 & a & 0.35 & $\mathrm{C}$ & 5.4 & $\mathrm{a}$ & 16.7 & $a b$ & 23.4 & $\mathrm{a}$ & 43 & n.s. & 41 & a & 18.8 & $\mathrm{a}$ & 6.1 & $c$ \\
\hline Manure & 6.30 & $b$ & 0.13 & $\mathrm{a}$ & 0.24 & $a b c$ & 0.35 & $\mathrm{bc}$ & 5.3 & $a b$ & 18.8 & $\mathrm{a}$ & 16.9 & $a b$ & 49 & n.s. & 40 & a & 14.7 & $a b$ & 15.1 & a \\
\hline Fish sludge & 6.17 & $\mathrm{~cd}$ & 0.10 & $b$ & 0.24 & $a b$ & 0.37 & $\mathrm{a}$ & 4.2 & $\mathrm{bc}$ & 9.7 & c & 13.2 & $b$ & 35 & n.s. & 24 & $a b$ & 14.8 & $a b$ & 11.9 & $a b$ \\
\hline Meat bone meal & 6.15 & $d$ & 0.09 & $b$ & 0.22 & C & 0.37 & $a b$ & 4.2 & $\mathrm{bc}$ & 12.5 & $\mathrm{bc}$ & 14.2 & $b$ & $29^{\circ}$ & n.s. & 12 & $b$ & 7.0 & c & 6.7 & c \\
\hline Wood ash & 6.45 & a & 0.14 & $\mathrm{a}$ & 0.22 & bc & 0.34 & C & 6.1 & $\mathrm{a}$ & 13.7 & $a b c$ & 15.5 & $b$ & 40 & n.s. & $43^{b}$ & a & 13.1 & $a b c$ & 9.8 & $\mathrm{bc}$ \\
\hline SEM & 0.02 & & 0.01 & & 0.01 & & 0.00 & & 0.3 & & 1.2 & & 1.7 & & 6 & & 5 & & 1.5 & & 0.9 & \\
\hline HSD & 0.08 & & 0.03 & & 0.03 & & 0.02 & & 1.2 & & 5.4 & & 7.6 & & 26 & & 26 & & 6.9 & & 4.3 & \\
\hline \multicolumn{23}{|c|}{ Two-way anova, source of variation } \\
\hline Treatment & 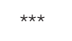 & & 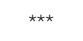 & & 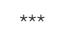 & & 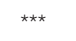 & & 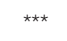 & & $\star \star \star ~$ & & 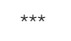 & & n.s. & & 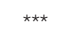 & & * & & $\star \star \star ~$ & \\
\hline Soil & 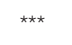 & & * & & $\star \star \star \star ~$ & & $\star \star \star *$ & & $\star \star$ & & 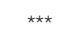 & & 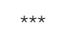 & & n.s. & & n.s. & & $\star \star \star$ & & 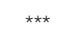 & \\
\hline Treatment $\times$ soil & n.s. & & $\star \star$ & & n.s. & & $* \star$ & & $\star \star$ & & * & & $\star \star$ & & n.s. & & n.s. & & * & & $\star \star \star ~$ & \\
\hline
\end{tabular}

HSD, Tukey's honest significant difference at each pH level, where values followed by the same letter are not significantly different; $n$.s., not significant.

*, **, and ${ }^{* * *}$ significant at $p<0.05,0.01$, and 0.001 probability level, respectively.

aTwo-way ANOVA based on log transformation.

${ }^{b}$ Only three observations.

'Only two observations.

¿One-way ANOVA without meat bone meal on unlimed soil and two-way ANOVA without meat bone meal.
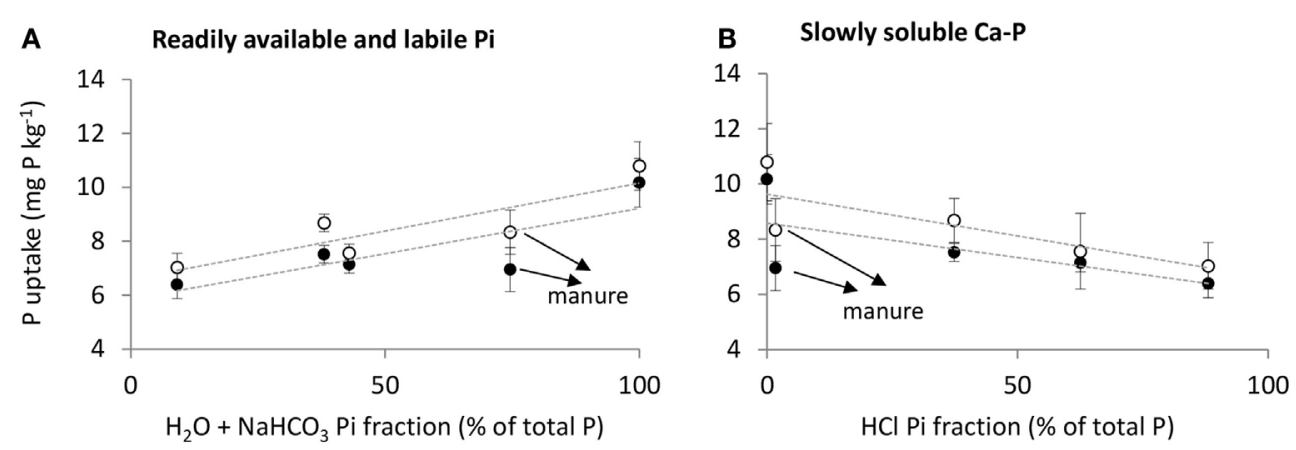

FIGURE 3 | Phosphorus uptake by barley ( $\mathrm{mg} \mathrm{P}^{-1}$ soil) as an effect of $(\mathrm{A}) \mathrm{H}_{2} \mathrm{O}+\mathrm{NaHCO}_{3}$-soluble inorganic $\mathrm{P}$ fraction and (B) $\mathrm{HCl}$-soluble inorganic $\mathbf{P}$ fraction in fertilizers for both soils $\left(\bullet=\right.$ unlimed soil and $\bullet=$ limed soil). All $\mathrm{P}$ in MinP was assumed to be present in the $\mathrm{H}_{2} \mathrm{O}+\mathrm{NaHCO}_{3} \mathrm{Pi}$ fraction. Error bars indicate SD of Pdf fertilizer between replicates.

solubility of fertilizer P applied to the soil. The Pmic measured 7 days after fertilizer application resulted in significant relationships with $\mathrm{P}$ uptake by barley. However, while the relationship was negative on the unlimed soil, it was positive on the limed soil. Soil $\mathrm{pH}$ was unable to explain the variation in $\mathrm{P}$ uptake by barley between fertilizer treatments.

\section{DISCUSSION}

\section{Effects of Inorganic P Species in Secondary Resources on P Uptake by Barley}

The P uptake by barley following secondary resource application was mainly affected by the solubility of the inorganic P species 
TABLE 6 | Results of simple linear regression with $Y=P$ uptake

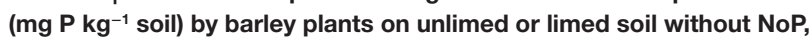
and $X=$ explanatory variables, where fertilizer characteristics are sequentially extracted inorganic $P(P i)$ fractions in secondary $P$ resources (Table 2), $C_{\mathrm{P}}=$ water-soluble $\mathrm{P}\left(\mathrm{mg} \mathrm{P} \mathrm{L}^{-1}\right), \boldsymbol{m}$ and $n=$ isotopic dilution parameters, $E_{1 \text { min }}=$ isotopically exchangeable $\mathrm{P}$ ( $\mathrm{mg} \mathrm{P} \mathrm{kg}^{-1}$ soil), Resin $\mathbf{P}=$ resin-extractable $\mathbf{P}$ ( $\mathbf{m g} \mathbf{P} \mathbf{k g}^{-1}$ soil), $\mathbf{P d f f}$ Resin $\mathbf{P}=\mathbf{P}$ derived from the fertilizer in the resin-extractable $\mathbf{P}$ pool (\%), and Pmic = microbial $\mathbf{P}$ ( $\mathrm{mg} \mathrm{P} \mathrm{kg}^{-1}$ soil), measured, respectively, 7 and 21 days after fertilizer application.

\begin{tabular}{|c|c|c|c|c|}
\hline & \multicolumn{2}{|c|}{ Unlimed soil } & \multicolumn{2}{|c|}{ Limed soila } \\
\hline & $R^{2}$ & $p$-value & $R^{2}$ & $p$-value \\
\hline \multicolumn{5}{|c|}{ Fertilizer characteristics } \\
\hline $\begin{array}{l}\mathrm{H}_{2} \mathrm{O}+\mathrm{NaHCO}_{3-} \\
\text { soluble } \mathrm{Pi}\end{array}$ & 0.55 & 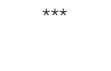 & 0.47 & 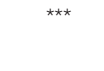 \\
\hline $\mathrm{HCl}$ fraction & 0.35 & ** & 0.41 & $\star \star$ \\
\hline \multicolumn{5}{|c|}{ Physicochemical soil processes } \\
\hline$C_{P}$ & 0.58 & 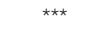 & 0.25 & * \\
\hline$m$ & 0.53 & 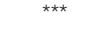 & 0.60 & 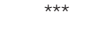 \\
\hline$n$ & $0.83^{c}$ & $\star \star \star ~$ & 0.05 & n.s. \\
\hline$E_{1 \min }$ & 0.38 & ** & 0.03 & n.s. \\
\hline Resin $P, 7$ days & 0.00 & n.s. & 0.08 & n.s. \\
\hline Pdff resin P, 7 days & 0.55 & 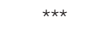 & 0.15 & n.s. \\
\hline Resin P, 21 days & 0.84 & 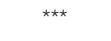 & 0.44 & $\star \star$ \\
\hline Pdff resin $P, 21$ days & 0.58 & 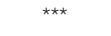 & 0.14 & n.s. \\
\hline $\begin{array}{l}\text { Soil pH (pot } \\
\text { experiment) }\end{array}$ & 0.02 & n.s. & 0.02 & n.s. \\
\hline \multicolumn{5}{|c|}{ Microbial soil processes } \\
\hline $\mathrm{P}$ mic, 7 days & $0.51^{\mathrm{b}, \mathrm{c}}$ & ** & 0.50 & 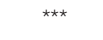 \\
\hline P mic, 21 days & 0.35 & 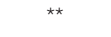 & 0.03 & n.s. \\
\hline
\end{tabular}

${ }^{*},{ }^{* *}$, and ${ }^{* * *}$ significant at $p<0.05,0.01$, and 0.001 probability level, respectively. n.s., not significant.

${ }^{a}$ Only three replicates of meat bone meal.

'Without meat bone meal.

cNegative relationship.

the resource contained. The indirect effects of the secondary resources studied on P uptake through their influences on physicochemical and microbial soil processes were generally of less importance.

Poor P uptake following meat bone meal application can be explained by its large fraction of Ca-bound $\mathrm{P}$ such as hydroxyapatite and chlorfluorapatite (7) with low solubility, especially in soils with $\mathrm{pH}>6.5$ (42). Similar results have been reported by Ylivainio et al. (18) and Brod et al. (7) after application of meat bone meal to ryegrass.

Fish sludge was the secondary resource that tended to result in the highest $\mathrm{P}$ uptake, probably because a considerable $\mathrm{P}$ fraction in fish sludge is readily available and labile, i.e., soluble in $\mathrm{H}_{2} \mathrm{O}$ and $\mathrm{NaHCO}_{3}$ (Table 2). However, fish sludge also contains apatite (7), which can explain why neither meat bone meal nor fish sludge increased $C_{\mathrm{P}}, E_{1 \mathrm{~min}}$, and Resin P over NoP in the limed soil of the incubation experiment.

Wood ash resulted in equally high $\mathrm{P}$ uptake as the other secondary resources, as expected from its large fraction of labile $\mathrm{Pi}$, in addition to slowly soluble $\mathrm{Ca}-\mathrm{P}$ [mainly $\left(\mathrm{Ca}_{2}\left(\mathrm{SiO}_{4}\right)\right)_{6} \mathrm{Ca}_{3}$ $\left.\left(\mathrm{PO}_{4}\right)_{2}\right]$ (7). The $\mathrm{P}$ uptake following wood ash application was equally high on both soils, but on the limed soil of the incubation experiment wood ash surprisingly increased $C_{\mathrm{P}}$ and $E_{1 \min }$ to the same level as MinP. Similarly, Brod et al. (7) found increasing P fertilization effects of the same wood ash with increasing soil $\mathrm{pH}$ and attributed this effect to the likely presence of $\mathrm{NaHCO}_{3}$-soluble $\mathrm{P}$ adsorbed to $\mathrm{Al}-/ \mathrm{Fe}$-(hydr)oxides. Wood ash was the secondary resource with the largest $\mathrm{NaHCO}_{3}$-soluble Pi fraction among all products studied. Phosphorus adsorbed to Al-/Fe-(hydr)oxides is characterized by increasing solubility with increasing soil $\mathrm{pH}$ (9). However, increased $C_{\mathrm{P}}$ and $E_{1 \mathrm{~min}}$ values after wood ash application on the limed soil could also be a methodological artifact if the magnetic stirrer mechanically destroyed $\left(\mathrm{Ca}_{2}\left(\mathrm{SiO}_{4}\right)\right)_{6} \mathrm{Ca}_{3}\left(\mathrm{PO}_{4}\right)_{2}$, thereby solubilizing phosphate, while the same stable $\mathrm{Ca}-\mathrm{P}$ was already solubilized in the unlimed soil. Similarly, Sinaj et al. (43) found that silicato-calcium phosphate present in Thomas slag quickly solubilized after application to an acidic soil with $\mathrm{pH}$ 6.2. A methodological artifact during determination of $E_{1 \mathrm{~min}}$ would explain why increased wood ash P solubility on the limed compared with the unlimed soil was not reflected by increased Pdf fertilizer in the pot experiment or elevated Resin P on the limed soil.

Manure resulted in lower $\mathrm{P}$ uptake by barley than MinP, even though $75 \%$ of $\mathrm{P}$ in manure was present as readily available and labile Pi (Table 2). Phosphorus uptake following manure application tended to be lower than expected from the linear regression lines with the $\mathrm{H}_{2} \mathrm{O}+\mathrm{NaHCO}_{3}$-soluble or $\mathrm{HCl}$-soluble $\mathrm{Pi}$ fractions as explanatory variables (Figure 3). Oberson et al. (44) also reported lower P fertilization effects of cow feces than di-ammonium phosphate after a pot experiment using indirect labeling and soils with different fertilization histories.

\section{Effects of Microbial Soil Processes on P Uptake by Barley}

Our results indicate that organic $\mathrm{C}$ applied with manure may have resulted in microbial immobilization of soluble $\mathrm{P}$, since Pdf soil ( $\mathrm{mg} \mathrm{P} \mathrm{kg}^{-1}$ ) in barley was significantly lower after manure application than after NoP on both soils (Figure 2). This is also in agreement with manure increasing Pmic, compared with MinP, on both soils after 21 days (Table 5). Oberson et al. (44) reported microbial $\mathrm{P}$ immobilization following cow feces application to soils with different fertilization histories, and Bünemann et al. (45) describe increases in Pmic as a result of glucose addition during an incubation experiment with a P-deficient tropical soil. On the limed soil in the present study, total P uptake by barley was lower for the manure than the MinP treatment, but Pdf fertilizer ( $\mathrm{mg} \mathrm{P} \mathrm{kg}^{-1}$ ) after manure application was equally high as after MinP. Therefore, the difference method would have underestimated the fertilization effect of manure because of microbial immobilization of soluble $\mathrm{P}$ in this soil and thereby a lower contribution from soil $\mathrm{P}$.

Even though organic $\mathrm{C}$ also was applied with fish sludge and meat bone meal, microbial P immobilization seems not to have been a major competitor to barley plants in these cases, and Pdf soil (mg P kg-1) was equally high as after MinP. At the same fertilization rate of $\mathrm{P}$, only 557 and $152 \mathrm{mg}$ organic $\mathrm{C} \mathrm{kg}^{-1}$ were applied with fish sludge and meat bone meal, compared with $2008 \mathrm{mg}$ organic $\mathrm{C} \mathrm{kg}^{-1}$ with manure (Table 2). In the incubation 
experiment, however, there were still signs of $\mathrm{P}$ immobilization, indicated as increased Pmic over NoP 21 days after application of fish sludge on the limed and meat bone meal on the unlimed soil (Table 5). This can be explained by a larger fraction of $\mathrm{C}$ in fish sludge and meat bone meal being soluble in $\mathrm{H}_{2} \mathrm{O}$ than the $\mathrm{C}$ in manure (Table 2). Accordingly, Bünemann et al. (46) point out a strong impact of C quality on microbial P immobilization. Still, due to too few products included in this study, we cannot specify the quantity and quality of organic $C$ in secondary resources at which $\mathrm{P}$ uptake by plants might be negatively affected by activated microbial activity. Furthermore, it remains unknown whether the effect of secondary resources on microbial soil processes is also negligible for plant $\mathrm{P}$ uptake on soils with high microbial activity, because in the present study Pmic in both soils was overall rather low (47).

\section{Effects of Physicochemical Soil Processes on P Uptake by Barley}

Phosphorus uptake by barley was higher on the limed than on the unlimed soil (Figure 2), probably because growing conditions were better overall. Barley is known to be sensitive to low soil $\mathrm{pH}$ [e.g., Ref. (48)], which is often associated with high concentrations of soluble Al. However, higher P uptake on the limed than on the unlimed soil could also be due to higher $\mathrm{P}$ availability, as supported by higher $\mathrm{P}$ concentration in plants receiving NoP (two-sided $t$-test, $n=8$ ) (Table 4). On the unlimed soil, more $\mathrm{P}$ was probably adsorbed to Al-/Fe-(hydr)oxides because of increased positive surface charges at lower soil $\mathrm{pH}$. The increased importance of $\mathrm{P}$ adsorption on the unlimed soil was also indicated by a decrease in Resin P over time, which was not observed in the limed soil (Table 5).

Wood ash caused a significant increase in soil $\mathrm{pH}$ on both soils as result of the liming effect of $\mathrm{CaCO}_{3}$. Increasing effects of wood ash on soil pH are well known [e.g., Ref. (49)]. However, the effect of wood ash on $\mathrm{pH}$ was far too small to significantly influence $\mathrm{P}$ availability in the soil (Table 6). Equally high Pdf soil ( $\mathrm{mg} \mathrm{P} \mathrm{kg}^{-1}$ ) after wood ash application and NoP showed that soil $\mathrm{P}$ availability was not affected by the $\mathrm{pH}$-increasing effect of wood ash within the $\mathrm{pH}$ range in the present experiment. With wood ash, only $0.1 \mathrm{~g} \mathrm{CaCO}_{3} \mathrm{~kg}^{-1}$ soil was applied $\left[8 \mathrm{wt} \% \mathrm{CaCO}_{3}\right.$ in wood ash according to Brod et al. (7)], in comparison with $2 \mathrm{~g} \mathrm{CaCO}_{3} \mathrm{~kg}^{-1}$ soil applied to the limed soil.

\section{Methodological Considerations}

Conducting the isotope dilution technique allowed us to conclude that the difference method would have led to similar results for $\mathrm{P}$ fertilization effects in this case, because P uptake by barley after secondary resource application was overall little affected by their influence on physicochemical and microbial soil processes. The underlying assumption in the difference method that fertilized and unfertilized treatments take up the same $\mathrm{P}$ amount from the soil would only have been violated after manure application due to microbial immobilization. Therefore, the results are also in agreement with those of a previous experiment in which a sand-peat mixture was used as a model soil (7), even though natural soil processes could not be studied. Thus, the results of the present study indicate that the difference method is reliable for secondary resources with low ratios of OM to P. However, these results should be confirmed with different soil types and extended with several secondary resources with a wide range of organic $\mathrm{C}$ content compared with $\mathrm{P}$.

The indirect labeling method is based on the assumptions that plant-available soil $\mathrm{P}$ is homogeneously labeled and that dilution of the radioisotope is only due to the unlabeled fertilizer. The internal control treatment MinPdir resulted in significantly higher Pdf soil and lower Pdf fertilizer than MinP according to a comparison of the two treatments over both soils. The difference between the directly and indirectly labeled mineral control treatment suggests that unlabeled soil P contributed to the dilution of the SA in plants in the MinP treatment, e.g., via the mineralization of organic or microbial P (44). This means that fertilization effects might have been slightly overestimated when the indirect method was used. In fact, significantly increased Pmic over NoP after MinP application on the limed soil after 7 days indicates modified microbial activity also in the mineral control treatment, even though no organic $\mathrm{C}$ was applied with MinP. In that case, soil microbes were probably stimulated as a methodological artifact by introducing oxygen when mixing the experimental soil, as suggested by Oberson et al. (50) and Bünemann et al. (51). Twenty-one days after fertilizer application, the microbial boost could no longer be observed.

Another methodological inconsistency was observed in the seed $\mathrm{P}$ experiment, where our results incorrectly indicated that the amount of $\mathrm{P}$ derived from the seed was larger than the amount applied with seed. It is possible that the acid-washed sand still contained $\mathrm{P}$, some $\mathrm{P}$ added with the two removed seeds had leaked into the soil, or P applied with the seed was underestimated because the seeds sown per pot were not weighed. In addition, large variation between the replicates of Pdf seed (Figure 1) and relatively low transfer from the seed compared with total P uptake might have contributed to the inconsistency. However, the actual reasons could not be identified. An alternative to the approach used here is to estimate Pdf seed by comparing the P content in the seeds at seedling stage and the remaining $\mathrm{P}$ content in the seeds at harvest, as suggested by Achat et al. (52). Several studies have pointed out the importance of correcting for seed P contribution when the indirect method is applied [e.g., Ref. $(22,36,52)]$ to avoid overestimation of $\mathrm{P}$ derived from the unlabeled fertilizer. Here, the fraction of Pdf seed in total P uptake was small in comparison with, e.g., results reported by Achat et al. (52), who used ryegrass and fescue as the experimental crop and suggested that $15-50 \%$ of P uptake at the first cut was Pdf seed. The difference between the different indirectly labeled treatments was also small and the relative fertilization effect of the secondary resources was not affected by Pdf seed.

\section{CONCLUSION}

This study explored the effects of secondary resources on physicochemical and microbial soil $\mathrm{P}$ processes and their importance for plant $\mathrm{P}$ uptake at two soil $\mathrm{pH}$ levels in the same arable soil. The main driver for $\mathrm{P}$ uptake was found to be the solubility of inorganic $\mathrm{P}$ species contained in the secondary resources, while indirect effects on $\mathrm{P}$ availability via influences on physicochemical 
and microbial soil processes were of little overall importance. This implies that $\mathrm{P}$ uptake following secondary resource application can be sufficiently predicted by intrinsic chemical $P$ characteristics. The $\mathrm{P}$ uptake by barley was indeed best explained by a linear positive relationship with the $\mathrm{H}_{2} \mathrm{O}+\mathrm{NaHCO}_{3}$-soluble inorganic $\mathrm{P}$ fraction and a linear negative relationship with the $\mathrm{HCl}$-soluble inorganic $\mathrm{P}$ fraction in fertilizers on both unlimed and limed soil. Organic $\mathrm{C}$ resulted in microbial immobilization of labile $\mathrm{P}$ and decreased uptake in barley of $\mathrm{P}$ derived from the soil only after manure application. In this arable soil with rather low microbial biomass $\mathrm{P}$, immobilization of $\mathrm{P}$ in microbial biomass could not challenge barley plants as the main P sink after application of fish sludge and meat bone meal. Further studies are needed to identify the critical organic $\mathrm{C}$ content in secondary resources at which microbial $\mathrm{P}$ processes influence plant $\mathrm{P}$ uptake. The significant increase in soil $\mathrm{pH}$ as result of wood ash application had no effect on $\mathrm{P}$ uptake by barley plants within the $\mathrm{pH}$ range in this study.

\section{AUTHOR CONTRIBUTIONS}

$\mathrm{EB}$ and $\mathrm{AO}$ designed the experiment; $\mathrm{EB}$ conducted the experiment; and EB analyzed the data with the help of $\mathrm{AO}$ and wrote the

\section{REFERENCES}

1. van Dijk KC, Lesschen JP, Oenema O. Phosphorus flows and balances of the European Union Member States. Sci Total Environ (2015) 542:1078-93. doi:10.1016/j.scitotenv.2015.08.048

2. Schoumans OF, Bouraoui F, Kabbe C, Oenema O, van Dijk K. Phosphorus management in Europe in a changing world. Ambio (2015) 44:180-92. doi:10.1007/s13280-014-0613-9

3. Withers PJA, van Dijk KC, Neset T-SS, Nesme T, Oenema O, Rubæk GH, et al. Stewardship to tackle global phosphorus inefficiency: the case of Europe. Ambio (2015) 44:193-206. doi:10.1007/s13280-014-0614-8

4. Hamilton H, Brod E, Hanserud O, Gracey E, Vestrum M, Steinhoff F, et al. Investigating cross-sectoral synergies through integrated aquaculture, fisheries, and agriculture phosphorus assessments: a case study of Norway. J Ind Ecol (2015). doi:10.1111/jiec.12324

5. Norwegian Environment Agency. Bedre utnyttelse av fosfor $i$ Norge. Rapport M-351. (2015). Available from: http://www.miljodirektoratet.no/no/ Publikasjoner/2015/Juni/Bedre-utnyttelse-av-fosfor-i-Norge/

6. Nanzer S, Oberson A, Huthwelker T, Eggenberger U, Frossard E. The molecular environment of phosphorus in sewage sludge ash: implications for bioavailability. J Environ Qual (2014) 43:1050-60. doi:10.2134/jeq2013.05.0202

7. Brod E, Øgaard AF, Hansen E, Wragg D, Haraldsen TK, Krogstad T. Waste products as alternative phosphorus fertilizer. Part I: inorganic P species affect fertilization effects depending on soil pH. Nutr Cycl Agroecosyst (2015) 103:167-85. doi:10.1007/s10705-015-9731-4

8. Hedley M, McLaughlin M. Reactions of phosphate fertilizers and by-products in soils. In: Sims TJ, Sharpley AN, editors. Phosphorus: Agriculture and the Environment. Madison, WI: American Society of Agronomy, Inc., Crop Science Society of America, Inc., Soil Science Society of America, Inc (2005). p. 181-252. Agronomy Monograph No. 46.

9. Lindsay WL. Chemical Equilibria in Soils. New York: John Wiley \& Sons (1979).

10. Brod E, Øgaard AF, Haraldsen TK, Krogstad T. Waste products as alternative phosphorus fertilizer. Part II: predicting $\mathrm{P}$ fertilization effects by chemical extraction. Nutr Cycl Agroecosyst (2015) 103:187-99. doi:10.1007/ s10705-015-9731-4

11. McLaughlin MJ, Alston AM. The relative contribution of plant residues and fertilizer to the phosphorus nutrition of wheat in a pasture/cereal system. Aust J Soil Res (1986) 24:517-26. doi:10.1071/SR9860517 paper. All authors contributed to the interpretation of the results, and read and approved the manuscript.

\section{FUNDING}

This work was part of the research projects CenBio (Bioenergy Innovation Centre, Grant No. 193817) and Innovative utilization of wood ash (Grant No. 215935). Both are co-funded by the Research Council of Norway and research and industry partners. The cooperation on which the present study was based was enabled by the research project IMPROVE-P, which is funded by transnational funding bodies that are partners of the FP7 ERA-net project, and CORE Organic Plus, with cofunding from the European Commission. We thank Dr. L. Schönholzer (ETH Zürich) for support with the analytical methods.

\section{SUPPLEMENTARY MATERIAL}

The Supplementary Material for this article can be found online at http://journal.frontiersin.org/article/10.3389/fnut.2016. 00012

12. Oberson A, Joner E. Microbial turnover of phosphorus in soil. In: Turner BL, Frossard E, Baldwin DS, editors. Organic Phosphorus in the Environment. Wallingford: CAB International (2005). p. 133-64.

13. Øgaard A. Effect of fresh and composted cattle manure on phosphate retention in soil. Acta Agric Scand Sect B Soil Plant Sci (1996) 46:98-105.

14. Jakobsen I, Leggett ME, Richardson AE. Rhizosphere microorganisms and plant phosphorus uptake. In: Sims TJ, Sharpley AN, editors. Phosphorus: Agriculture and the Environment. Madison, WI: American Society of Agronomy, Inc., Crop Science Society of America, Inc., Soil Science Society of America, Inc (2005). p. 437-94. Agronomy Monograph No. 46.

15. Achat DL, Daumer M-L, Sperandio M, Santellani A-C, Morel C. Solubility and mobility of phosphorus recycled from dairy effluents and pig manures in incubated soils with different characteristics. Nutr Cycl Agroecosyst (2014) 99:1-15. doi:10.1007/s10705-014-9614-0

16. Erich MS. Agronomic effectiveness of wood ash as source of phosphorus and potassium. J Environ Qual (1991) 20:576-81. doi:10.2134/jeq1991.203576x

17. Jeng AS, Haraldsen TK, Grønlund A, Pedersen PA. Meat and bone meal as nitrogen and phosphorus fertilizer to cereals and rye grass. Nutr Cycl Agroecosyst (2006) 76:183-91. doi:10.1007/s10705-005-5170-y

18. Ylivainio K, Uusitalo R, Turtola E. Meat bone meal and fox manure as P sources for ryegrass (Lolium multiflorum) grown on a limed soil. Nutr Cycl Agroecosyst (2008) 81:267-78. doi:10.1007/s10705-007-9162-y

19. Morel C, Fardeau JC. The uptake by crops of fresh and residual phosphatic fertilizers by simultaneous measurements with ${ }^{32} \mathrm{P}$ and ${ }^{33} \mathrm{P}$. Appl Radiat Isot (1989) 40:273-8. doi:10.1016/0883-2889(89)90217-7

20. Frossard E, Sinaj S, Zhang LM, Morel JL. The fate of sludge phosphorus in soil-plant systems. Soil Sci Soc Am J (1996) 60:1248-53. doi:10.2136/sssaj199 $6.03615995006000040041 \mathrm{x}$

21. Frossard E, Achat DL, Bernasconi SM, Bünemann E, Fardeau J-C, Jansa J, et al. The use of tracers to investigate phosphate cycling in soil-plant systems. In: Bünemann EK, editor. Phosphorus in Action. Berlin, Heidelberg: Springer Verlag (2011). p. 59-91.

22. Nanzer S, Oberson A, Berger L, Berset E, Hermann L, Frossard E. The plant availability of phosphorus from thermo-chemically treated sewage sludge ashes as studied by ${ }^{33} \mathrm{P}$ labelling techniques. Plant Soil (2014) 377:439-56. doi:10.1007/s11104-013-1968-6

23. EN ISO 11885. Water Quality: Determination of Selected Elements by Inductively Coupled Plasma Optical Emission Spectrometry (ICP-OES). Brussels: CEN (2009). 
24. Norwegian Ministry of Agriculture and Food. Forskrift om gjødselvarer mv. av organisk opphav. (2003). Available from: http://www.lovdata.no/for/sf/ld/ xd-20030704-0951.html\#27

25. EC. Regulation (EC) No 1774/2002 of the European Parliament and of the Council of 3 October 2002 Laying Down Health Rules Concerning Animal by-Products Not Intended for Human Consumption. (2002). Available from: http://eur-lex.europa. eu/legal-content/EN/TXT/PDF/?uri=CELEX:32002R1774\&from=EN

26. Møberg JP, Petersen L. Øvelsesvejledning til geologi og jordbundsloere II. København: Den Kongelige Veterinær- og Landbohøyskole (1982).

27. Murphy J, Riley JP. A modified single solution method for the determination of phosphate in natural waters. Anal Chim Acta (1962) 27:31-6. doi:10.1016/ S0003-2670(00)88444-5

28. EN 13654-1. Soil Improvers and Growing Media: Determination of Nitrogen. Part 1: Modified Kjeldahl Method. Brussels: CEN (2001).

29. Henriksen A, Selmer-Olsen AR. Automatic methods for determining nitrate and nitrite in water and soil extracts. Analyst (1970) 95:514-8. doi:10.1039/ an9709500514

30. Selmer-Olsen AR. Determination of ammonium in soil extracts by an automated indophenol method. Analyst (1971) 96:565-8. doi:10.1039/ an9719600565

31. NIBIO. WRB Grupper. (2015). Available from: http://kilden.skogoglandskap. no/?topic $=$ jordsmonn $\& \mathrm{X}=7334000.00 \& \mathrm{Y}=400000.00 \&$ zoom $=0 \&$ lang $=\mathrm{n}-$ b\&bgLayer $=$ graatone_cache\&layers $=$ jm_wrb_grupper\&layers_opacity $=0.75$

32. Egnér H, Riehm H, Domingo WR. Untersuchungen über die chemische Bodenanalyse als Grundlage für die Beurteilung des Nährstoffzustandes der Böden. Kungl Lantbrukshögskolans Annaler (1960) 26:199-215.

33. van Reeuwijk LP. Procedures for Soil Analysis. 12-2. Acid Oxalate Extractable $\mathrm{Fe}$. Wageningen: FAO (1995).

34. Zadoks JC, Chang TT, Konzak CF. A decimal code for the growth stages of cereals. Weed Res (1974) 14:415-21. doi:10.1111/j.1365-3180.1974.tb01084.x

35. Ohno T, Zibilske LM. Determination of low concentrations of phosphorus in soil extracts using malachite green. Soil Sci Soc Am J (1991) 55:892-5. doi:10.2136/sssaj1991.03615995005500030046x

36. Pypers P, Van Loon L, Diels J, Abaidoo R, Smolders E, Merckx R. Plantavailable $\mathrm{P}$ for maize and cowpea in P-deficient soils from the Nigerian Northern Guinea savannah - comparison of E- and L-values. Plant Soil (2006) 283:251-64. doi:10.1007/s11104-006-0016-1

37. Fardeau JC, Guiraud G, Marol C. The role of isotopic techniques on the evaluation of the agronomic effectiveness of P fertilizers. Fert Res (1996) 45:101-9. doi:10.1007/BF00790659

38. SAS Institute Inc. JMP ${ }^{\circledR}$, Version 11.1.1. Cary, NY: SAS Institute Inc. (2013).

39. Liebisch F, Bünemann EK, Huguenin-Elie O, Jeangros B, Frossard E, Oberson A. Plant phosphorus nutrition indicators evaluated in agricultural grasslands managed at different intensities. Eur J Agron (2013) 44:67-77. doi:10.1016/j. eja.2012.08.004

40. Lemaire G, Jeuffroy M-H, Gastal F. Diagnosis tool for plant and crop N status in vegetative stage: theory and practices for crop N management. Eur J Agron (2008) 28:614-24. doi:10.1016/j.eja.2008.01.005

41. Hedley MJ, Stewart JWB, Chauhan BS. Changes in inorganic and organic soil phosphorus fractions induced by cultivation practices and by laboratory incubations. Soil Sci Soc Am J (1982) 46:970-6. doi:10.2136/sssaj1982.03615 995004600050017x
42. Morel C, Fardeau JC. Agronomical evaluation of phosphate fertilizer as a nutrient source of phosphorus in crops: isotopic procedure. Fert Res (1990) 24:115-22. doi:10.1007/BF01073230

43. Sinaj S, Frossard E, Fardeau JC, Lhote F, Morel JL. Observation directe de l'altération de scories de déphosphoration après incorporation dans un sol acide cultivé. C R Acad Sci Sér II (1994) 319:1207-14.

44. Oberson A, Tagmann HU, Langmeier M, Dubois D, Mäder P, Frossard E. Fresh and residual phosphorus uptake by ryegrass from soils with different fertilization histories. Plant Soil (2010) 334:391-407. doi:10.1007/ s11104-010-0390-6

45. Bünemann EK, Smithson PC, Jama B, Frossard E, Oberson A. Maize productivity and nutrient dynamics in maize-fallow rotations in western Kenya. Plant Soil (2004) 264:195-208. doi:10.1023/ B:PLSO.0000047749.43017.fd

46. Bünemann E, Bossio DA, Smithson PC, Frossard E, Oberson A. Microbial community composition and substrate use in a highly weathered soil as affected by crop rotation and P fertilization. Soil Biol Biochem (2004) 36:889-901. doi:10.1016/j.soilbio.2004.02.002

47. Frossard E, Buchmann N, Bünemann EK, Kiba DI, Lompo F, Oberson A, et al. Soil properties and not inputs control carbon, nitrogen, phosphorus ratios in cropped soils in the long-term. Soil Discuss (2015) 2:995-1038. doi:10.5194/ soild-2-995-2015

48. Bona L, Wright RJ, Baligar VC, Matuz J. Screening wheat and other small grains for acid soil tolerance. Landscape Urban Plan (1993) 27:175-8. doi:10.1016/0169-2046(93)90046-G

49. Demeyer A, Voundi Nkana JC, Verloo MG. Characteristics of wood ash and influence on soil properties and nutrient uptake: an overview. Bioresource Technol (2001) 77:287-95. doi:10.1016/S0960-8524(00)00043-2

50. Oberson A, Friesen DK, Rao IM, Bühler S, Frossard E. Phosphorus transformations in an Oxisol under contrasting land-use systems: the role of the soil microbial biomass. Plant Soil (2001) 237:197-210. doi:10.102 3/A:1013301716913

51. Bünemann E, Marschner P, McNeill AM, McLaughlin MJ. Measuring rates of gross and net mineralisation of organic phosphorus in soils. Soil Biol Biochem (2007) 39:900-13. doi:10.1016/j.soilbio.2006.10.009

52. Achat DL, Sperandio M, Daumer M-L, Santellani A-C, Prud'Homme L, Akhtar M, et al. Plant-availability of phosphorus recycled from pig manures and dairy effluents as assessed by isotopic labelling techniques. Geoderma (2014) 23(2-234):24-33. doi:10.1016/j.geoderma.2014.04.028

Conflict of Interest Statement: The authors declare that the research was conducted in the absence of any commercial or financial relationships that could be construed as a potential conflict of interest.

Copyright (c) 2016 Brod, Øgaard, Krogstad, Haraldsen, Frossard and Oberson. This is an open-access article distributed under the terms of the Creative Commons Attribution License (CC BY). The use, distribution or reproduction in other forums is permitted, provided the original author(s) or licensor are credited and that the original publication in this journal is cited, in accordance with accepted academic practice. No use, distribution or reproduction is permitted which does not comply with these terms. 